Geological Magazine

www.cambridge.org/geo

\section{Review Article}

Cite this article: Runnegar B (2022) Following the logic behind biological interpretations of the Ediacaran biotas. Geological Magazine 159: 1093-1117. https://doi.org/10.1017/

S0016756821000443

Received: 12 January 2021

Revised: 30 April 2021

Accepted: 4 May 2021

First published online: 14 July 2021

\section{Keywords:}

Ediacaran; Ediacara fauna; history; relationships

Author for correspondence: Bruce Runnegar, Email: runnegar@ucla.edu

\title{
Following the logic behind biological interpretations of the Ediacaran biotas
}

Bruce Runnegar (1)

Department of Earth, Planetary and Space Sciences and Molecular Biology Institute, University of California, Los Angeles, CA 90095-1567, USA

\begin{abstract}
For almost 150 years, megascopic structures in siliciclastic sequences of terminal Precambrian age have been frustratingly difficult to characterize and classify. As with all other areas of human knowledge, progress with exploration, documentation and understanding is growing at an exponential rate. Nevertheless, there is much to be learned from following the evolution of the logic behind the biological interpretations of these enigmatic fossils. Here, I review the history of discovery as well as some long-established core members of widely recognized clades that are still difficult to graft on to the tree of life. These 'orphan plesions' occupy roles that were once held by famous former Problematica, such as archaeocyaths, graptolites and rudist bivalves. In some of those cases, taxonomic enlightenment was brought about by the discovery of new characters; in others it required a better knowledge of their living counterparts. Can we use these approaches to rescue the Ediacaran orphans? Five taxa that are examined in this context are Arborea (Arboreomorpha), Dickinsonia (Dickinsoniomorpha), Pteridinium plus Ernietta (Erniettomorpha) and Kimberella (Bilateria?). With the possible exception of Dickinsonia, all of these organisms may be coelenterate grade eumetazoans.
\end{abstract}

(c) The Author(s), 2021. Published by Cambridge University Press. This is an Open Access article, distributed under the terms of the Creative Commons Attribution licence (http:// creativecommons.org/licenses/by/4.0/), which permits unrestricted re-use, distribution and reproduction, provided the original article is properly cited.

\section{CAMBRIDGE UNIVERSITY PRESS}

\section{Introduction}

Most of the early discoveries of Ediacaran fossils were serendipitous (Richter, 1955; Ford. 1958; Anderson \& Misra, 1968; Keller \& Fedonkin, 1976; Minicucci, 2017), but Reg Sprigg (1919-1994) was actually looking for early animals when he found the holotype of Ediacaria flindersi (Fig. 1) at Ediacara in March 1946 (Sprigg, 1947, 1988). Furthermore, he found just what he and the World had expected: a jellyfish from the 'age of jellyfishes' (Sprigg, 1949, p. 97) - a concept that may have been influenced by C. D. Walcott's monograph Fossil Medusae (Walcott, 1898), the report of a probable jellyfish, Brooksella canyonensis, from the Neoproterozoic Nankoweap Formation of the Grand Canyon (Bassler, 1941; Glaessner, 1962) and possibly by Gürich's (1933) report of half a jellyfish (Paramedusium africanum) from the Nama beds of southern Africa. Sprigg was undoubtedly also encouraged by Kenneth Caster's comprehensive report of a new fossil jellyfish (Kirklandia texana) from the Cretaceous of Texas (Caster, 1945), which he referenced in 1949. Almost all of these objects are now thought to be either trace or pseudofossils (Fürsich \& Kennedy, 1975; Runnegar \& Fedonkin, 1992). Nevertheless, Sprigg's jellyfish hypothesis for the nature and mode of preservation of some of the most abundant Ediacaran fossils was widely influential for nearly 50 years, both in Australia (Glaessner, 1961, 1984; Wade, 1972b; Oliver \& Coates, 1987; Jenkins, 1989) and in the Soviet Union (Fedonkin, 1985a, 1987). How did Sprigg's jellyfish hypothesis arise and remain viable for so long? What other major hypotheses have been advanced to explain the Ediacara fauna? How have tradition, national proclivities and innovative thinking helped or hindered our understanding of the true nature of the Ediacara biota? These are some of the matters that are explored in this article.

\section{Ediacaran hypotheses}

\section{2.a. Sprigg's jellyfish hypothesis (1947+)}

Sprigg's exposure to dehydrating jellyfish on Adelaide's fine beaches (Sprigg, 1989) preconditioned his assignment of Ediacaria and other discoidal 'medusoids' to the cnidarian classes Hydrozoa and Scyphozoa. Not realizing that the invariably convex discs were on bed bases rather than bed tops, he saw them as jellyfish stranded by tides. This powerful imagery was adopted by Martin Glaessner when he moved to the University of Adelaide and began working on the Ediacara fauna (Fig. 1) and was inherited by Glaessner's successor - Richard Jenkins and Glaessner's students, despite clear evidence for bed base preservation and subtidal deposition (Gehling, 2000; McMahon et al. 2021). It was Jim Gehling's reinterpretation of the environment of deposition of the Ediacara Member (Gehling, 2000) and his work with 


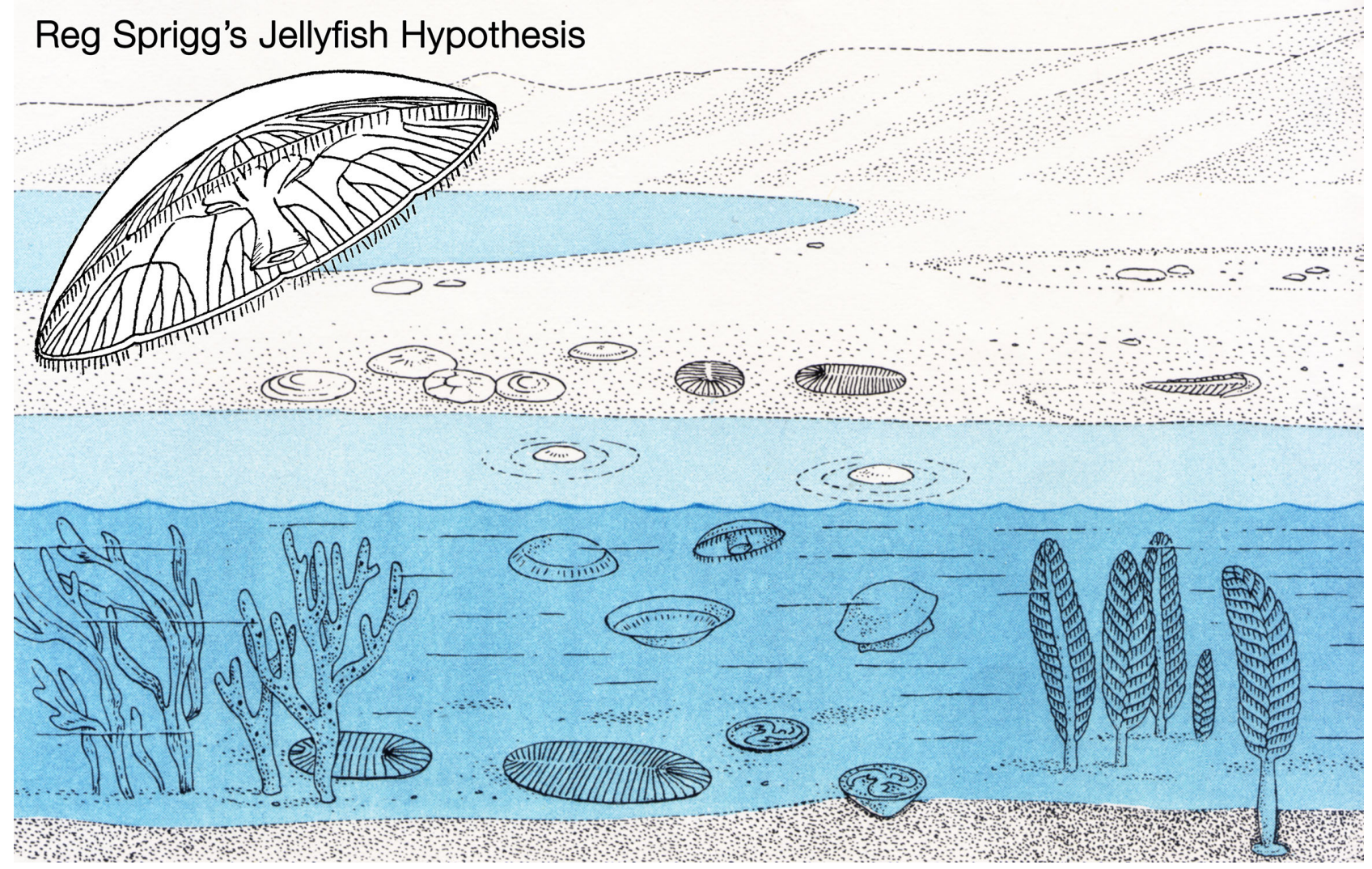

Fig. 1. Martin Glaessner's illustration of Sprigg's jellyfish hypothesis for the nature of the common Ediacaran fossils and their environment of deposition at Ediacara, South Australia plus his own Pennatulacea hypothesis, including a manifestation of Ford's chimera (Fig. 2, bottom right). Insert at upper left is Sprigg's reconstruction of the scyphozoan jellyfish Ediacaria flindersi. After Glaessner (1961) and Sprigg (1949, fig. 3B); @ Bunji Tagawa 1961, republished with permission and with a Creative Commons Licence, respectively.

Guy Narbonne on the true nature of Aspidella Billings, 1872 (Gehling et al. 2000) that ultimately killed the jellyfish hypothesis. Nevertheless, before it died Ediacaran 'medusoids' had been confidently placed in most extant and many extinct medusozoan classes: Hydrozoa, Scyphozoa, Cubozoa, Conulata, Dipleurozoa, Cyclozoa, Inordozoa, Trilobozoa (Sprigg, 1949; Harrington \& Moore, 1955; Glaessner \& Wade, 1971; Wade, 1972b; Jenkins, 1984; Sun, 1986; Fedonkin, 1987; Oliver \& Coates, 1987). It is sobering to appreciate that four classic Ediacaran jellyfish Ediacaria Sprigg, 1947 (Scyphozoa), Cyclomedusa Sprigg, 1947 (Cyclozoa), Protodipleurosoma Sprigg, 1949 (Hydrozoa) and Irridinitus Fedonkin, 1983 (Inordozoa) - are no more than preservational variants of the holdfast of a single species of Arborea Glaessner \& Wade, 1966 (Ivantsov, 2016).

\section{2.b. Glaessner's Pennatulacea hypothesis (1959+)}

Martin Glaessner (1906-1989) and Curt Teichert (1905-1996) were the first palaeontologists to view and collect Ediacaran fossils in South Australia. Both examined the holotype of Ediacaria flindersi during an ANZAAS meeting in Adelaide in August 1946, and Teichert travelled with Sprigg and his wife to Ediacara in 1947. However, it was Glaessner rather than Teichert who seized the opportunity after he moved to the University of Adelaide in 1950.

Sprigg's jellyfish hypothesis was supplemented by two major embellishments during the 1950s. Remarkably they came from discoveries in all three of the now recognized Ediacaran associations: Avalon (Charnwood), White Sea (Ediacara) and Nama (Namibia)
(Gehling \& Droser, 2013). Working with newly collected material from Namibia, Rudolf Richter (1881-1957) showed that Pteridinium simplex Gürich, 1933, which had previously been thought to resemble a fern, was constructed of three separate vanes, each being formed of tubular modules (Richter, 1955). As the only living animals having this kind of triradial geometry are gorgoniid octocorals, the cnidarian or 'coelenterate' affinity of Ediacarans received additional support. Then in 1958, Trevor Ford (1925-2017) reported Roger Mason's discovery of Charnia and Charniodiscus in England (Fig. 2). At the time, Ford preferred an algal rather than an animal affinity for these two fronds but reluctantly yielded to a letter Glaessner published soon afterwards in Nature entitled 'Precambrian Coelenterata from Australia, Africa and England' (Glaessner, 1959b; Ford, 1980). According to Glaessner, the taxa we now know as rangeomorphs and arboreomorphs were pennatulacean octocorals and thus both highly derived cnidarians but also colonies that had achieved a high degree of integration that allowed them to act as collective 'individuals' (Dewel et al. 2001). This concept of complex coloniality was elaborately developed by Hans D. Pflug as the Petalonamae hypothesis for the common taxa of the Nama Association (Pflug, 1966, 1970, 1971, 1972a).

\section{2.c. Pflug's Petalonamae hypothesis (1966+)}

Glaessner had a couple of opportunities to doubt his own pennatulacean hypothesis but his belief in it may have overwhelmed his objectivity: a lesson for us all. As a native German speaker, he had read Gürich and Richter's descriptions of Pteridinium carefully 


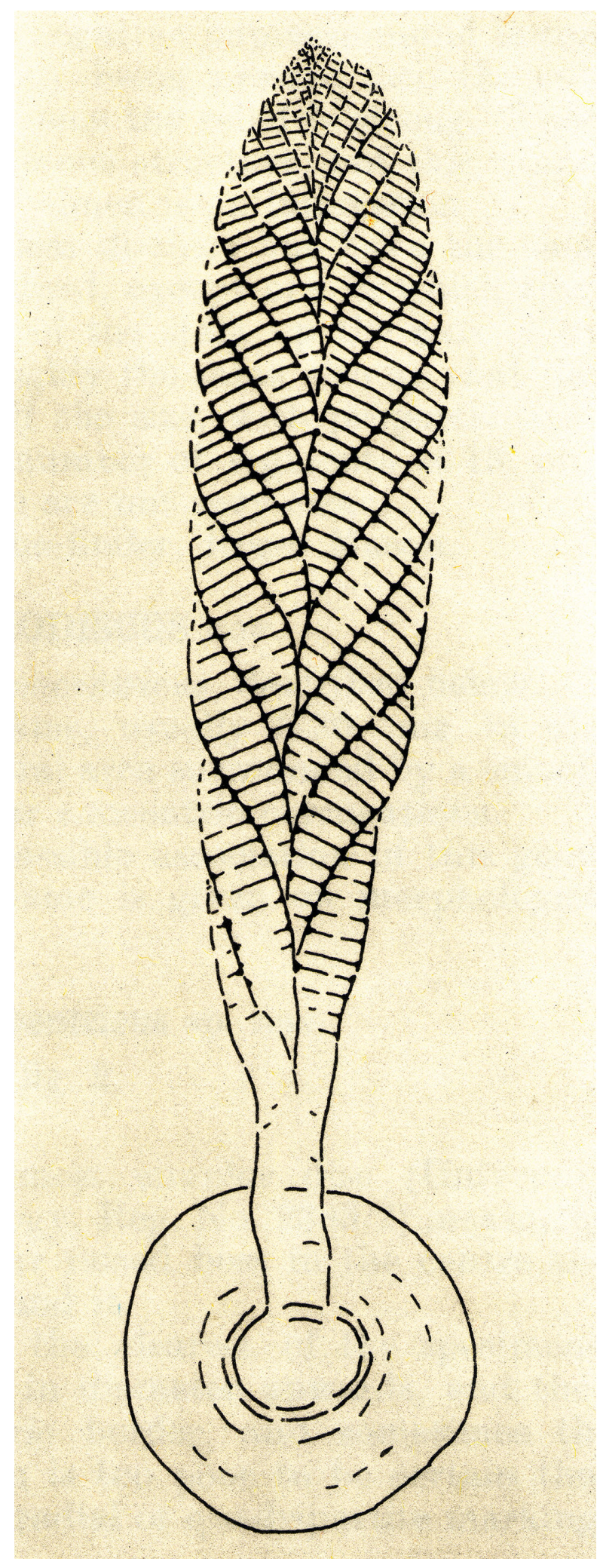

Fig. 2. Trevor Ford's chimera based on the frond of the rangeomorph Charnia and the holdfast of the arboreomorph Charniodiscus bridges the gulf between the two clades; both from the North Quarry of the Charnwood Golf Course, Leicestershire, UK, a locality discovered by Roger Mason in 1957 (Ford, 1958, fig. 3); (c) Yorkshire Geological Society 1958 , republished with permission. and was intimately familiar with fine specimens from Aar figured by Richter (1955), which he compared with small collections from the same site lent to him by the Geological Survey of South Africa and the Museum of Southwest Africa, Windhoek. Even so, he made no mention of the possibility of a third vane and instead emphasized similarities between Pteridinium and 'Rangea' (= Arborea), including his erroneous idea that both had primary and secondary orders of ribbing. He concluded that Pteridinium was a member of the Pennatulacea belonging to Richter's extinct family Pteridiniidae, incertae sedis (Glaessner, 1959a, 1963).

The second opportunity followed Mary Wade's 1964 discovery of a few fragments of Pteridinium simplex in a mass flow channel deposit at Ediacara. This Nama-style preservation was unique for South Australia, and neither Glaessner nor Wade seems to have realized that their best specimen (Glaessner \& Wade, 1966, pl. 101, figs 1-3) shows clear evidence for three vanes. Unsurprisingly, they also concluded that Pteridinium and Rangea, as well as Arborea, were members of the Pennatulacea. However, only a few months earlier, Pflug (1966) had described another small collection from Aar Farm and had begun to build a radically different hypothesis based initially on shared features of Pteridinium and his new genus, Ernietta (Fig. 3).

For the Petalonamae hypothesis, Pflug merged the morphology of average specimens of Ernietta with deformed U-shaped individuals of Pteridinium that had been transported and buried by storm surge sands at the Aar Lagerstätte locality (Meyer et al. 2014b, figs 3-5; Pflug, 1970, pl. 23, figs 1, 3; Richter, 1955, pl. 7, fig. 11). In his mind - and if I have it right - the bag-shaped body (corpus) was formed of leaves or vanes (petaloids) made from co-aligned tubular modules, each of which housed an individual (persona) of the colony. Branching of the modules was sympodial rather than dichotomous, opposite, alternate or monopodial, resulting in zig-zag junctions between adjacent petaloids. In some forms the petaloids were replicated like the layers of an onion and adjacent petaloids or sets of petaloids curved to enclose a 'petaloid cavity' (centrarium). Channels between sets of petaloids (petalodia) served as gullets. Clade disparity was summarized using five shape categories and five alternative positions for the 'ingestion aperture' (Pflug, 1972a, table 1).

Richard Jenkins demolished this house of cards with the pithy statement: 'One of us (Jenkins) has examined Pflug's material and considers that all the specimens he refers to as the "Erniettomorpha" belong to a single genus and species, Ernietta plateauensis Pflug' (Jenkins et al. 1981, p. 71). Pflug's theories would retain only academic interest except for the fact that he was a fine observer, so his drawings and descriptions are a major resource. However, maybe his concept of a centrarium is not as crazy as it seems and is worth a second look?

Gibson et al. $(2019,2021)$ built a life-sized numerical model of an Ernietta from Aar and then used computational fluid dynamics and flume experiments with a 3D-printed version of the flask-like model to investigate how Ernietta might have used ambient water motion in feeding. They concluded that the observed gregarious growth allowed nutrient-rich water to preferentially enter the body cavity (Pflug's centrarium), which was 'likely the location of nutrient acquisition' (Gibson et al. 2021, p. 146). This process of an animal co-opting a piece of the external environment to develop a metabolically useful internal body cavity may be widespread. It was or is realised to lesser or greater extents in 
(a)

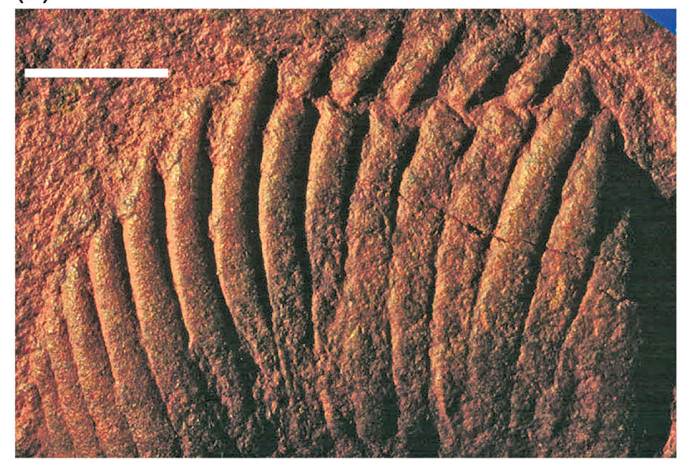

(b)

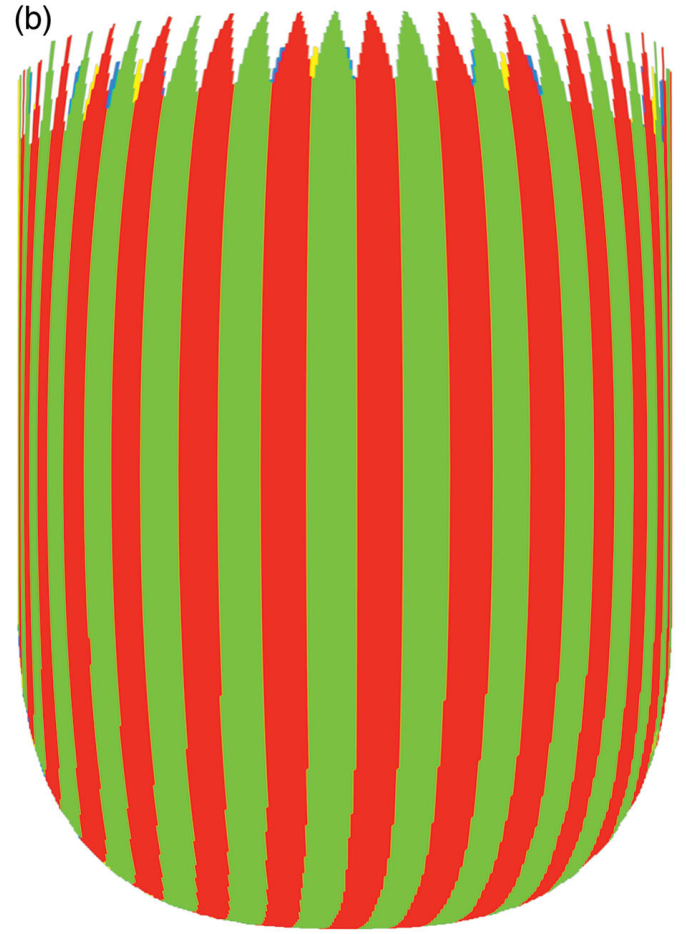

(c)

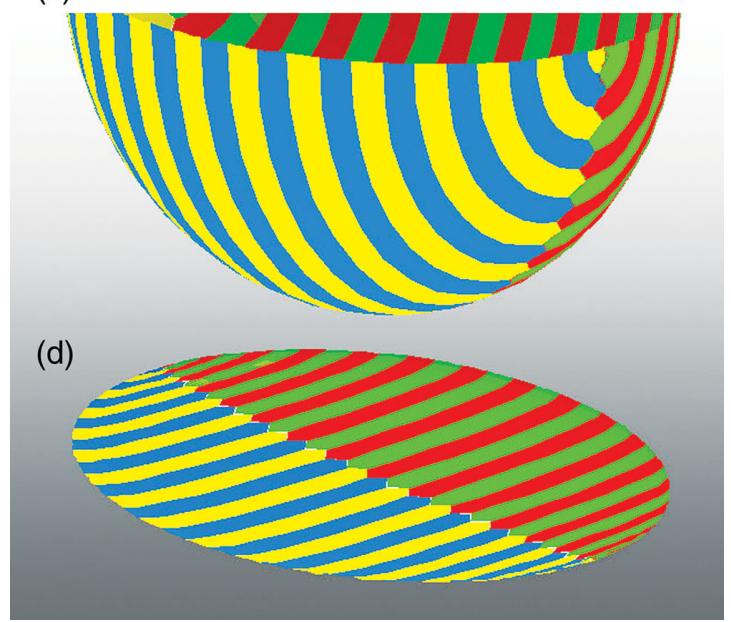

Fig. 3. (a) Ernietta plateauensis, Lower Member, Wood Canyon Formation, near Johnnie, Nevada, USA, specimen collected by Robert Horodyski, UCLA L7333-4, scale bar $=1 \mathrm{~cm}$. (b, c) 3D models of Ernietta with tapered growing module tips and plane of symmetry parallel to the axial seam. (d) Model of the base of Ernietta shown in (c) has been reduced to nearly zero thickness in the $\mathrm{Z}$ direction to illustrate the topological relationship between (c) Ernietta and (d) Phyllozoon. the atria of sponges and archaeocyaths, the cnidarian coelenteron, the bilaterian gut, the molluscan mantle cavity, the water vascular system of echinoderms, the chordate branchial basket, the marsupial pouch and the human lung. We could even extend the concept to the covid pod, if we were to go beyond the body. Thus, the centrarium of Ernietta could be part of a pathway to the coelenteron, as discussed in Section 6.c.

Pflug thought that the ancestral petalonamid might have resembled the colonial ciliate Zoothamnium (e.g. Bright et al. 2019). From there he saw a transition through Arborea and Charnia to Rangea, Pteridinium and Ernietta with much complexity added by preservational variants of each type. Here, I limit Petalonamae to three clades, Arboreomorpha, Rangeomorpha and Erniettomorpha (Erwin et al. 2011), and treat dickinsoniomorphs under 'Proarticulata' (contra Hoyal Cuthill \& Han, 2018).

\section{2.d. Seilacher's Vendozoa hypothesis (1983+)}

Dolf Seilacher (1925-2014) was struggling with understanding the Ediacaran organisms as early as 1976, when we began the discussion during a trip to the trace fossil-rich marine Permian of the southern Sydney Basin, initiated and organized by Bruce McCarthy, during the International Geological Congress (Cooper \& Branagan, 2015). At that time, Seilacher thought that they may have been megascopic prokaryotes. I remember well his subsequent presentation at the annual meeting of the Geological Society of America in Indianapolis in 1983, where he aired the Vendozoa concept, and Stephen Jay Gould's enthusiastic reaction to it, despite the fact that Gould (1941-2002) was suffering severely from treatment for mesothelioma. The rest is history, but Gould served well as Seilacher's bulldog in promoting the vendozoan hypothesis (Gould, 1984).

Seilacher tried to place all of the soft-bodied Ediacaran organisms in a single clade, but even he had to allow some exceptions, most notably for the 'sand corals' (Psammocorallia) and the trace fossils (Seilacher, 1989, 1992). Originally conceived as something akin to stem lineage animals, vendozoans soon became vendobionts with their affinities transferred to the rhizopodan protists, specifically foraminiferans and xenophyophores (Seilacher, 1992, 2003). These kinds of alveolates are now far removed from the Opisthokonta, which includes the animals and fungi, but their supergroup (TSAR) is closer to the Archaeplastida (a.k.a. 'plants') than to the supergroup containing the opisthokonts (Amorphea; Burki et al. 2020). In that sense, both Petalonamae and Vendobionta conform to the notion of an extinct kingdom somewhere between animals and plants, which was what Pflug thought.

Other aspects of the vendozoan hypothesis can also be traced to Pflug's ideas, although the Petalonamae were specifically excluded from the original proposal (Seilacher, 1989, p. 237). Both Pflug and Seilacher emphasized the modular construction for tubular units as the unifying feature of this extinct clade and the mechanism that allowed growth to proceed to larger body sizes than had previously been possible.

\section{2.e. Fedonkin's Proarticulata hypothesis (1985+)}

The holotype of Dickinsonia is incomplete so, with the jellyfish hypothesis in mind, Sprigg reconstructed it as being 'symmetrical across both longitudinal and transverse planes' (Sprigg, 1947, p. 222). Even though this was clearly untrue after Sprigg's second description of the fauna (Sprigg, 1949), Harrington \& Moore 
(1955) still made Dickinsonia the only known example of their new coelenterate class Dipleurozoa. Perceptively, Glaessner thought that Dickinsonia 'resembles certain worms more than any coelenterate' (Glaessner, 1958, 1959a; Glaessner \& Daily, 1959, p. 379). This idea was firmed up soon afterwards using comparisons of Dickinsonia and Spriggina Glaessner, 1958 with the highly derived extant polychaetes Spinther and Tomopteris, respectively (Glaessner, 1959a, 1961). Perhaps stimulated by Sidnie Manton's (1902-1979) lead article on Spinther in the new Journal of Natural History (Manton, 1967), Mary Wade (1928-2005) promoted Dickinsonia as a primitive polychaete 'derived from ancestors with biramous parapodia and a more normal, elongate shape'. This idea was falsified by Runnegar (1982) who showed that, unlike Spinther, Dickinsonia did not develop its discoidal shape from a vermiform juvenile growth stage (Zakrevskaya \& Ivantsov, 2020).

Dickinsonia was discovered on the Onega Peninsular of the White Sea coast of Russia by M. A. Fedonkin in the summer of 1975 (Keller \& Fedonkin, 1976). Better specimens obtained during the next decade suggested that the animal was not precisely bilaterally symmetrical. Rather, its segments alternated across the midline producing what has become known as 'slide' or 'glide' symmetry (Fig. 4). This is something like the zig-zag axial junctions of the petaloids of Pflug's erniettomorphs, but was generally interpreted in Russia as offset metamerism rather than mere geometric packing. In 1985, Fedonkin $(1985 b, 1998)$ proposed the new phylum Proarticulata to house Dickinsonia (Class Dipleurozoa), Vendia Keller, 1969 and related forms. Since then, Andrey Ivantsov and his colleagues have greatly expanded our knowledge and understanding of this proarticulate clade and the putative trace fossils associated with some of its members (Ivantsov, 1999, 2004, 2007, 2011, 2013; Ivantsov \& Malakhovskaya, 2002; Ivantsov et al. 2019a,b,c; Ivantsov et al. 2020; Ivantsov \& Zakrevskaya, 2021a).

At the time Proarticulata was proposed, similarities in the segmentation of annelids and arthropods were still being used as evidence for their common ancestry (Scholtz, 2002). Now that it is clear that Articulata (Annelida + Arthropoda) is not a valid group, it is trivially easy to reject the Proarticulata hypothesis (Dunn \& Liu, 2019). However, maybe this is throwing out the baby with the bathwater; a better approach may be to ask whether the repeated isomers/modules/units of the proarticulates share any pattern-forming processes with those controlling segmentation in annelids, arthropoda and chordates. It has become clear that segmentation in those clades evolved convergently (Seaver, 2003; Chipman, 2010; Evans et al. 2021). However, seriation of some sort must have a long history in all three main bilaterian clades. For example, early branching panarthropods such as Aysheaia Walcott have stereotypical sets of annulated lobopodial limbs (Chipman \& Edgecombe, 2019), implying that earlier vermiform ecdysozoans had probably already acquired the axial patterning that could be co-opted for generating appropriately spaced legs, as envisaged by Erwin (2020). These possibilities are explored below.

\section{Age and duration of the Ediacara biota}

When I entered the University of Queensland early in 1959, Dorothy Hill (1907-1997) began the palaeontology lectures with the then prevalent first approximation that there was no evidence
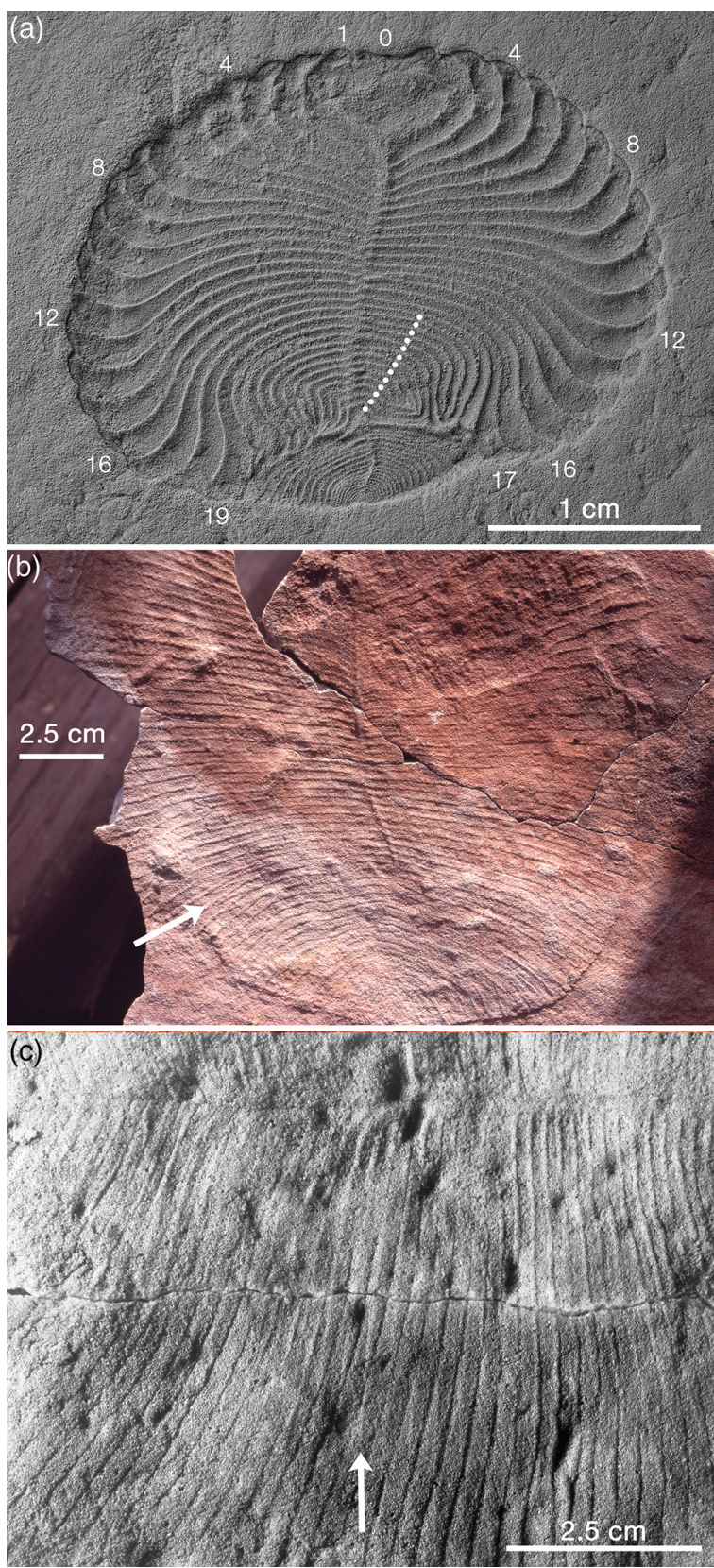

Fig. 4. Anatomical details of Dickinsonia. (a) Beautifully preserved specimen of $D$. cf. menneri that survived a non-lethal injury and regenerated its tailpiece. The first 17 modules grew normally but the following 13 modules (white dots) were damaged and then grew abnormally (in some cases joining up distally); a new tailpiece was generated from the axis and grew in such a way as to rebuild the oval body outline. Note that although some modules appear to be offset across the midline, others are clearly not offset, and the same number of modules occurs on both sides of the body; RAS PIN 4716/5187, Lyamtsa Formation, Onega Peninsula, Russia, image courtesy of A. Yu. Ivantsov. (b) Unusually large incomplete specimen of $D$. costata, which displays evidence for both upper and lower surfaces, as shown by the Y-shaped intersections of the module walls (arrow), and it illustrates the ambiguity frequently seen in proarticulates with respect to glide symmetry versus strictly bilateral symmetry; SAM P58615, Ediacara Sandstone Member, Rawnsley Quartzite, Parachilna Gorge. (c) Part of complete specimen of $D$. costata that also shows both surfaces; arrow points to one of several ridges that reflect one surface of the organism whereas the grooves they cross at a small angle represent the other surface; Sperling \& Vinther (2010, fig. S1) identified this specimen as Dickinsonia rex and regarded it as a 'footprint', not a body fossil; SAM P58616, Ediacara Sandstone Member, Rawnsley Quartzite, Ediacara, South Australia. 
for life before the Cambrian; the preceding $~ 3.5$ billion years of Earth history were 'Azoic'. The tide, however, had already turned; Ford's (1958) article on the Precambrian age of Charnia and Charniodiscus was on its way to Australia by boat, and Glaessner's (1959b) letter to Nature was about to appear. Furthermore, Arthur Holmes' (1890-1965) final attempt at a radiometrically calibrated geological timescale, which estimated the base of the Cambrian to be $600 \pm 20 \mathrm{Ma}$, would be published by the end of the year (Holmes, 1959). Fast-forward to the present. The base of the Cambrian is now constrained to be between 538.4 and $538.8 \mathrm{Ma}$ based on recent $\mathrm{U}-\mathrm{Pb}$ ages from Namibia and Mexico (Linnemann et al. 2019; Hodgin et al. 2020); the oldest Ediacarans postdate the Gaskiers glaciation in American Avalonia at $574 \mathrm{Ma}$ (Pu et al. 2016; Matthews et al. 2021); and the acme of the Ediacaran biota (White Sea assemblage), measured in terms of both diversity and disparity, existed from $>558$ to $<555 \mathrm{Ma}$.

\section{FAQs (frequently asked questions)}

\section{4.a. Were the Ediacaran fossils lichens?}

Greg Retallack had this 'annoying idea' in 1988 and found it surprisingly difficult to falsify (Retallack, 1992, 1994). Judging from the plethora of critiques his numerous articles dealing with this scenario have attracted, others have found it just as hard to accept. Here, we shall limit the discussion to five key elements of the lichen hypothesis: (1) Were the resistant Ediacaran organisms, which are preserved as external moulds on bed bases, woody like plants (Retallack, 1994)? (2) Are the Ediacaran fossils preserved in fossil soils (Retallack, 2012, 2013)? (3) Is the red colour of Australian Ediacaran sediments primary or secondary (Retallack, 2012)? (4) Did the Ediacaran organisms live on land, in the sea or both (Retallack, 2013, 2014)? (5) Were the Ediacaran organisms lichens or fungi (Retallack, 1994, 2007, 2016)?

(1) Woody or not? Wade's (1968) landmark paper on the preservation of the fossils at Ediacara set the stage for all subsequent work on this topic. She recognized the distinction between resistant animals, which are preserved as external moulds on the bases of beds, and non-resistant ones whose bodies collapsed upon burial. Perceptively, she attributed the formation of counterpart casts to upward movement of relatively incompetent sediment from the underlying bed. This process has been explored experimentally by Bobrovskiy et al. (2019). We might term it the waterbed hypothesis, one that requires a flexible but inextensible membrane (the mattress), the incompressible fluid it encloses and the bed frame, which holds the mattress in place (Press, 1978). At Ediacara, these could have been the microbial mat on which the organisms were living, the water-filled pore spaces beneath the mat and the laterally unbounded hydrostatic pressure within the sediment.

The principal alternative is the death mask hypothesis (Gehling, 1999), which requires early mineral cements (iron sulfides or quartz) to support the overlying bed during the decay of the organism (Tarhan et al. 2016; Liu et al. 2019). I prefer the waterbed hypothesis because it relies on conditions that may be regarded as ubiquitous, given the tight association between the fossils and the matgrounds on which they were preserved. Early mineralization fuelled by the decay of organic matter would have had to be remarkably selective to invariably distinguish between resistant and non-resistant organisms, whereas their different resistances to
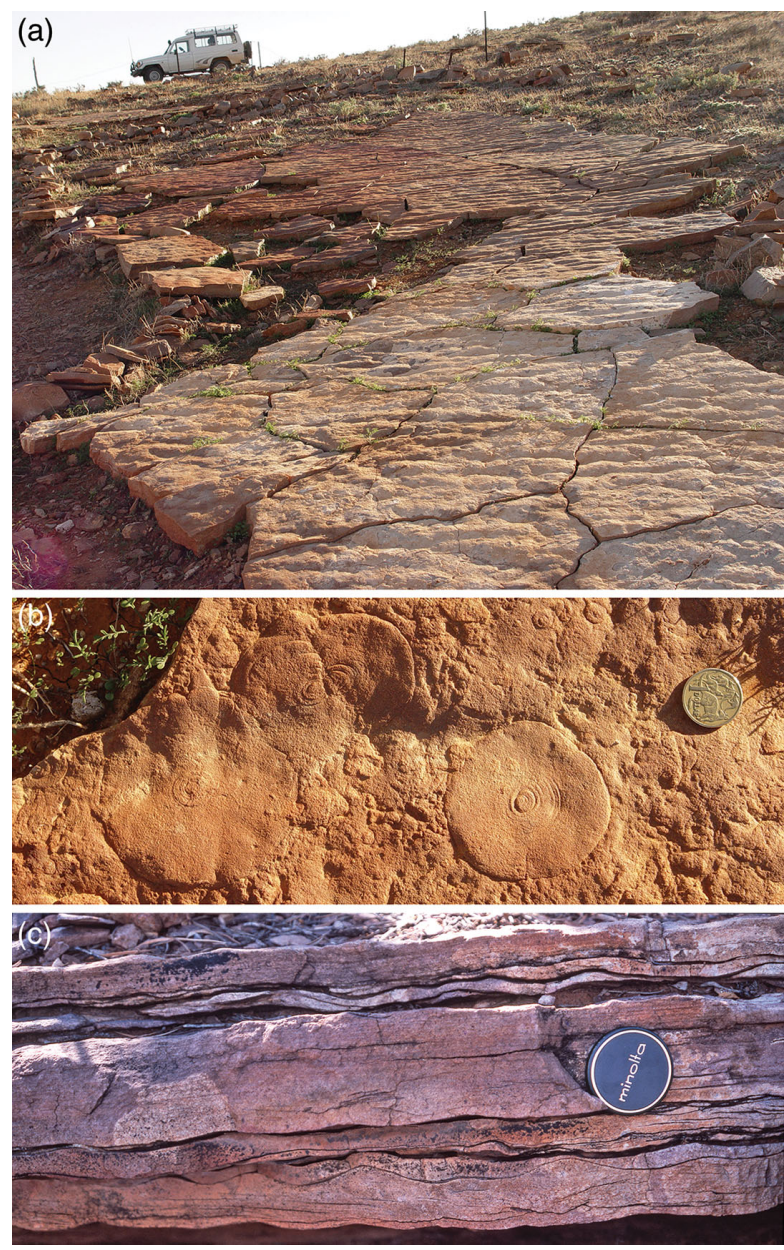

Fig. 5. Fossiliferous flaggy sandstones at the (a, b) Nilpena National Heritage Ediacaran fossil reserve and (c) Mt Scott Range, western Flinders Ranges, South Australia. Retallack (2016) considered these kinds of deposits to be palaeosols, formed on a braided stream floodplain $\sim 60 \mathrm{~km}$ inland from the Ediacaran shoreline. The standard view is that they were deposited in a shallow marine environment below fair weather wave base. Overturned bed in (a) is TC-MM3, the lower surface of which (b) is dominated by frond holdfasts (Droser et al. 2019). Seen in cross-section (c), these beds bear no resemblance to palaeosols. Coin in (b) and lens cap in (c) are $25 \mathrm{~mm}$ and $60 \mathrm{~mm}$ in diameter, respectively.

loading should have achieved that automatically. More experimentation is clearly needed. In any case, Retallack (1994) completely misunderstood the nature of the preservation of the resistant organisms when he compared them with various fossil woods (Waggoner, 1995). This argument for a lichen affinity is not sustainable.

(2) Are the fossils on terrestrial soils or marine matgrounds? This is a difficult question to address generally so the focus will be on three specific examples. The richly fossiliferous beds at the western edge of the Flinders Ranges (Nilpena, Ediacara, Mt Scott Range) are packages of thin, ripple-marked flaggy sandstones and even thinner intervening sandy 'shims' (Fig. 5; Tarhan et al. 2017). Retallack (2019, p. 64) considered these sites to have been $\sim 60 \mathrm{~km}$ inland from the Ediacaran coast and attributed the shims to wind deposition during dry seasons. These clean, sandy quartzites (Fig. 5c) display no textural or chemical evidence for soil formation, so if the Ediacaran organisms were living on these barren braided floodplains, they were doing so in a nutrient-poor environment exposed to enhanced UV under an oxygen-depleted atmosphere (Li et al. 2020). The arboreomorphs, in particular, may 


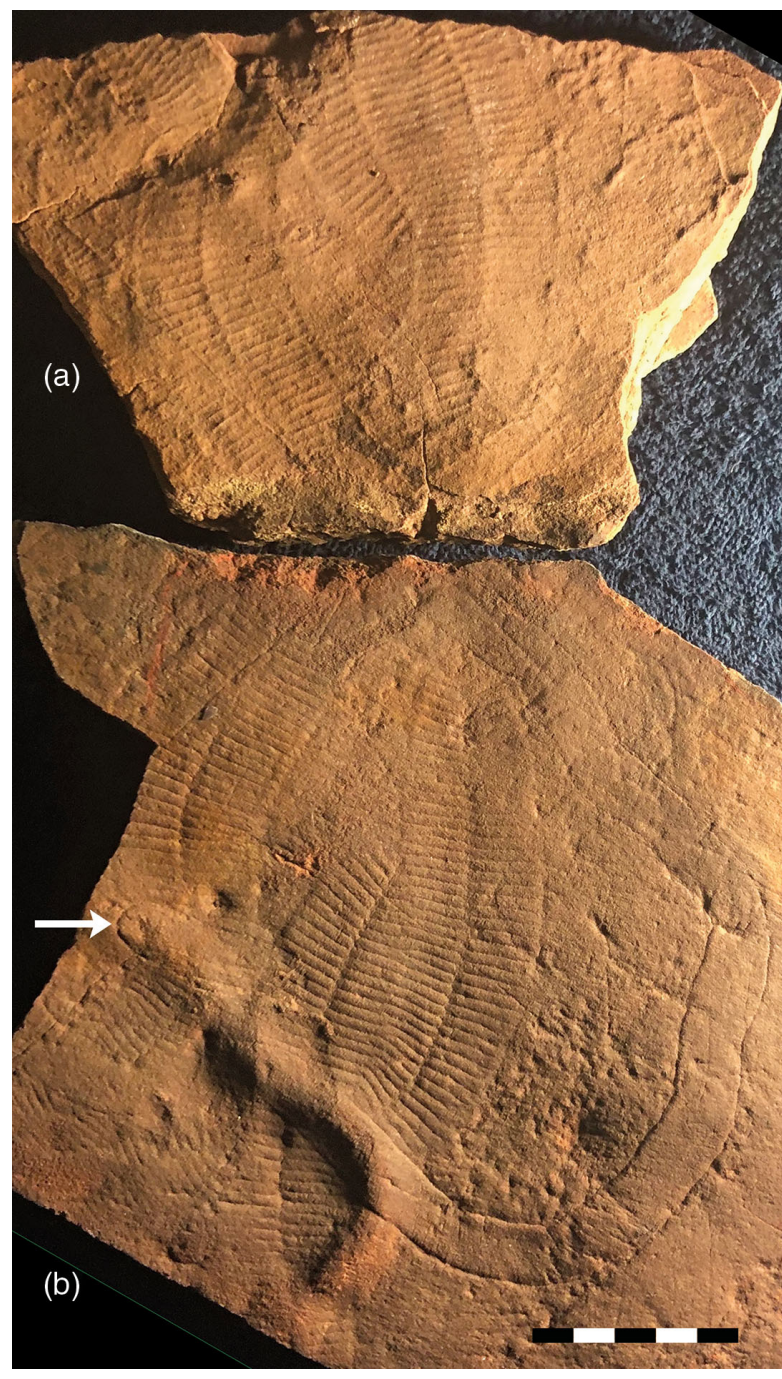

Fig. 6. Fronds of Phyllozoon hanseni and tubes of Aulozoon soliorum on a piece of a 3$4 \mathrm{~cm}$ thick event bed from Bathtub Gorge, central Flinders Ranges (Gehling \& Runnegar, 2021). The counterpart (a) is the top of the A horizon of a Muru palaeosol according to Retallack (2013). Both event bed and 'palaeosol' are thin, laminated quartz sandstones; the terrestrial palaeosol interpretation is clearly falsified by this example. Arrow marks apparently closed end of one Aulozoon tube. Scale in centimetres. Image courtesy of J. G. Gehling.

have had a hard time. Yet they persisted, becoming as frequent as $\sim 60 \mathrm{~m}^{-2}$ in this hostile situation (Droser et al. 2006). Alternatively, if these beds were produced by storm waves in a quiet subtidal setting (Gehling, 2000; Gehling \& Droser, 2013; McMahon et al. 2021), life for the arboreomorphs should have been easier, as it presumably was beneath the photic zone in Avalonia (Wood et al. 2003). The extraordinary ecological range implied by identifying the Nilpena flaggy sandstones as fossil soils is one of the best reasons for rejecting the lichen hypothesis.

A second specific example is the 'Muru pedotype' found beneath a 3-4 cm thick event bed in Bathtub Gorge, central Flinders Ranges, that buried and preserved a death assemblage of Phyllozoon fronds, Aulozoon tubes and Dickinsonia footprints (Gehling \& Runnegar, 2021; Retallack, 2013, p. SI4). In this case, the underlying, equally thin sandstone, which is covered with counterpart casts of fossils found on the base of the overlying event bed, is well lithified and easily extracted from the outcrop (Fig. 6). There is no textural or chemical evidence for the A, B and
C horizons of the type Muru pedotype (Fig. 6a, b). Suggestions that Phyllozoon was a window lichen and Aulozoon a mycelial rhizome, with Dickinsonia as its mushroom (thallus; Retallack, 2007), are imaginative but unrealistic, given the fact that the putative rhizomes are in the event bed that buried the organisms, not in the underlying 'palaeosol' (Fig. 6; Gehling \& Runnegar, 2021).

The third specific example is from Brachina Gorge, central Flinders Ranges, the type locality for the Wadni and Muru pedotypes (Fig. 7; Retallack, 2012). As we know from political debates, facts are not necessarily enough to overcome deeply held beliefs. In this case, the one example that might help tip the balance is the preservation of Dickinsonia, Parvancorina Glaessner, 1958 and other taxa on the distended lower surfaces of large load casts at the base of a sandstone bed in Brachina Gorge, central Flinders Ranges (Fig. 7). According to Retallack (2012), this bed is the C horizon of the type section of his Muru pedotype and was deposited in a sandy river channel before being deformed, not by hydrostatic foundering, but by glacial ice moving over the A horizon loess. This special pleading is necessary to explain sedimentary structures that are otherwise readily attributed to liquefaction or fluidization in aquatic environments (e.g. Owen, 1996). Furthermore, the woody properties attributed to Dickinsonia under the lichen hypothesis (Retallack, 1994, 2007) are not expressed in the curvature of a sizeable individual preserved on the convex surface of one rounded load cast (Fig. 7e-g). In each of these examples, the sandstones underlying the fossils have no features of fossil soils and in two of the three cases (Nilpena and Bathtub Gorge) closely resemble sandstones that overlie the fossils. In the third example (Brachina Gorge), the 'palaeosol' is a red siltstone that is directly overlain by a thick quartz sandstone that has undergone soft-sediment deformation typical of shallow marine conditions (McMahon et al. 2021). There is little reason for regarding any of these sediments as terrestrial.

(3) Are the red beds oxidized soils or just outback Australia? Australia's 'red centre' is legendary and the default explanation is regolith chemistry, which has oxidized an ancient landscape that in places may date back to the Mesozoic Era (Twidale, 2016). The difficulty of distinguishing between primary ferric components and those that have been generated by post-depositional processes is exemplified by the saga of the Marble Bar Chert (Rasmussen et al. 2014), where the red colour was for a time used to argue for an oxygen-rich Archaean atmosphere. The red silts in Brachina Gorge, which characterize the type Wadni and Muru pedotypes (Retallack, 2012, 2013), are far more likely to be the products of Cenozoic weathering than Ediacaran soil formation (Pillans, 2018).

(4) Were the organisms terrestrial, marine or both? Although Retallack has considered almost every fossiliferous Ediacaran deposit - even Avalonian Newfoundland (Retallack, 2014) - to be no deeper than intertidal, the credibility of his arguments diminishes with distance from South Australia. If the evidence there is equivocal at best, there is little in favour of a terrestrial habitat at any of the classic soft-bodied sites.

(5) Do the fossils themselves resemble lichens or fungi more than animals or plants? This question has been thoroughly explored (Lücking \& Nelsen, 2018) and the definite answer is 'no, they do not'. The lichen hypothesis is a false lead that has taken up too much space in the literature.

\section{4.b. Were Ediacaran organisms colonial?}

Rangea, Charnia and Charniodiscus automatically became highly individualized colonial animals by Glaessner's (1959b) promotion 
(a)
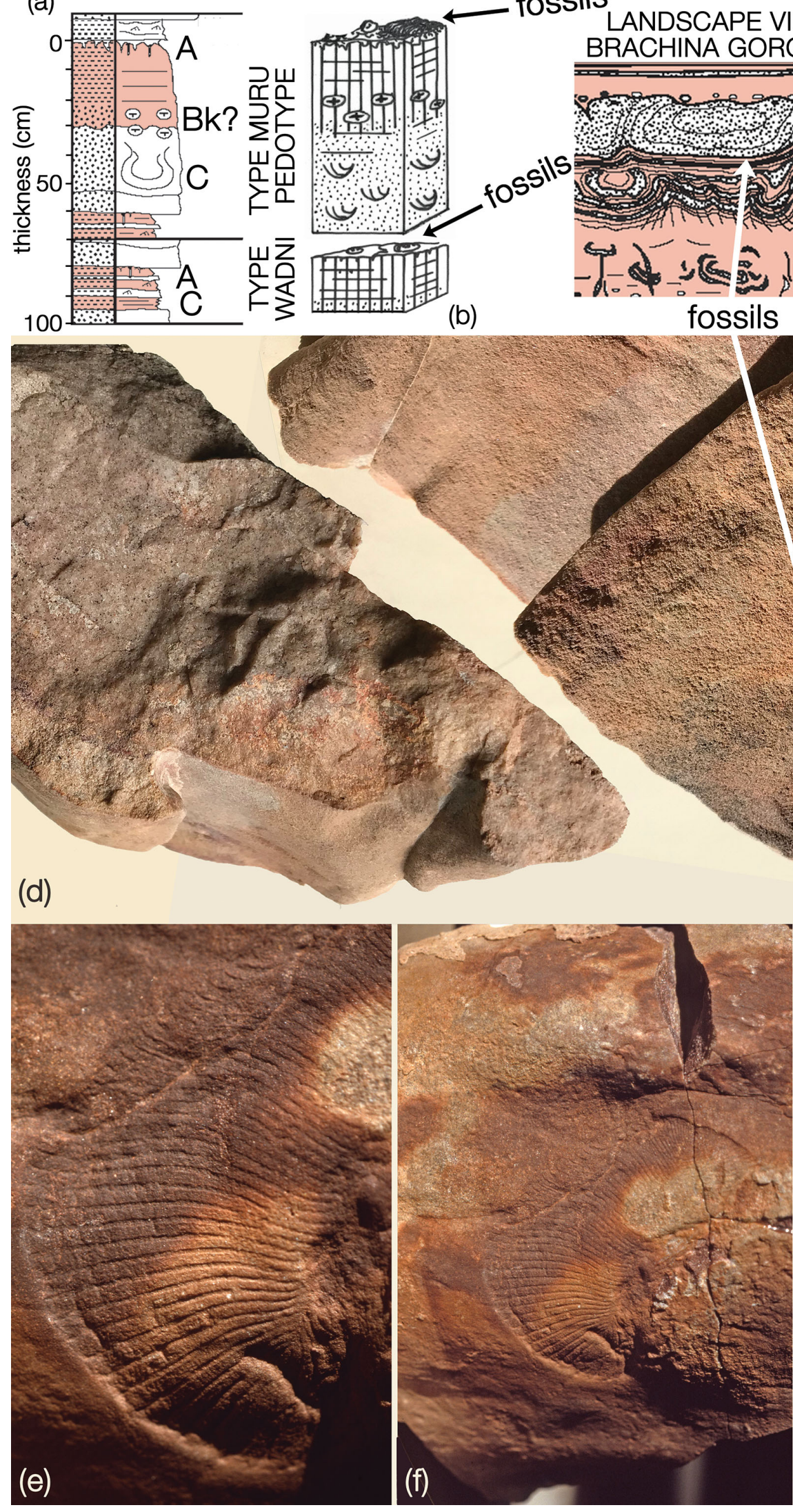

fossils

ш๖ نु نु

之㟧

山之

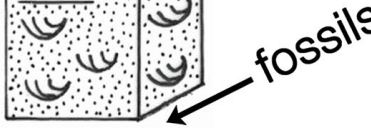

(b) fossils

LANDSCAPE VIEW OF OUTCROP BRACHINA GORGE HEYSEN RANGE
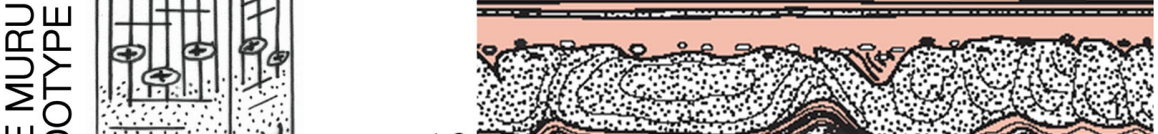

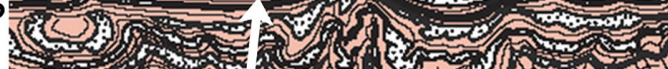

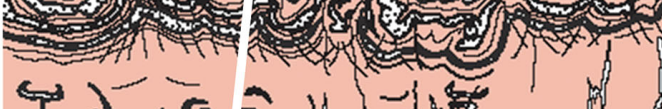

Th

(c) 
of the pennatulacean octocoral hypothesis for these frondose forms from Avalonia, Namibia and Australia. This hypothesis was widely accepted (Jenkins, 1985; Oliver \& Coates, 1987) until falsified after almost 50 years by Waggoner \& Collins (2002) using a molecular clock, and by Antcliffe \& Brasier (2006), who contrasted their modes of growth and development. Pennatulacean octocorals are highly evolved cnidarians, well removed from basal groups, so their ability to operate as innervated individuals is a derived feature of the clade. Nevertheless, by attributing this ability to many of the Namibian Petalonamae, Pflug $(1971,1972 a)$ saw a transition from frondose taxa such as Rangea and Arborea to animal-like colonies with some of the attributes of echinoderms, arthropods, molluscs and even chordates. These fanciful ideas were based mainly on preservational variants of the three common Namibian genera - Rangea Gürich, 1930, Pteridinium and Ernietta - and have no relevance now other than historical interest. However, Dewel et al. (2001) advanced a much more sophisticated and well-received hypothesis along similar lines, using Pteridinium, Charnia, Rangea and Arborea as examples of the progress of colonial duplication and integration during Ediacaran time. In this scheme, the pennatulacean-level integration of Arborea allowed it to operate as a self-sufficient mobile individual and raised the possibility that animals such as Dickinsonia might show how colony integration led to bilaterian segmentation. However, as none of these organisms seems to have been colonial except in the most elementary way (Landing et al. 2018), colonialism per se was probably not the evolutionary pathway to more familiar animals (but see Ivantsov, 2016 for a different view). Nevertheless, life is built on the LEGO Principle (McKay, 2004). Think elements, biomolecules, ribosomes, cells, organs, segments, individuals, populations, guilds, biomes. In this sense, it is clonal construction rather than colonial construction that characterizes the Ediacaran organisms.

\section{4.c. How and what did Ediacaran organisms eat?}

Seilacher (1989) had to confront this issue because he could not rely on the mechanisms that were available to those who viewed the Ediacarans as coelenterates, worms and arthropods. $\mathrm{He}$ assumed all nutrition needed to be absorbed through the body wall and speculated that the organisms may have depended on endosymbionts for their sustenance (McMenamin, 1986). He discussed the possibility of photosymbionts for upright taxa in shallow water and chemosymbionts for deepwater taxa and 'mat recliners'. He even sketched out how endosymbionts in an organism like Dickinsonia could have exploited the oxic-anoxic interface of a matground, obtaining $\mathrm{H}_{2} \mathrm{~S}$ from below and oxygen from seawater. This remains a viable hypothesis for prostrate organisms (Gehling et al. 2005; McIlroy et al. 2021). The alternative for an almost sessile creature with no other food-collecting abilities is in situ ventral digestion of the kind used by the living placozoan Trichoplax (Sperling \& Vinther, 2010).

For the upright fronds and many other forms, all of which have high surface-to-volume ratios, osmotrophy has been the feeding mode of choice (Laflamme et al. 2009; Ghisalberti et al. 2014). However, Butterfield (2020) has made a strong case against having the food absorbed from the outside and instead argued that it was taken in and processed inside, more or less as sponges and cnidarians do. As the food in question is thought to be either dissolved organic carbon (DOC) or particulate organic carbon (POC), I dub these two possibilities the DOC POOL (external feeding) and DOC POC (internal feeding) hypotheses (Fig. 8a). The Devonian rugose corals Heliophyllum and Crepidophyllum, which had digestive
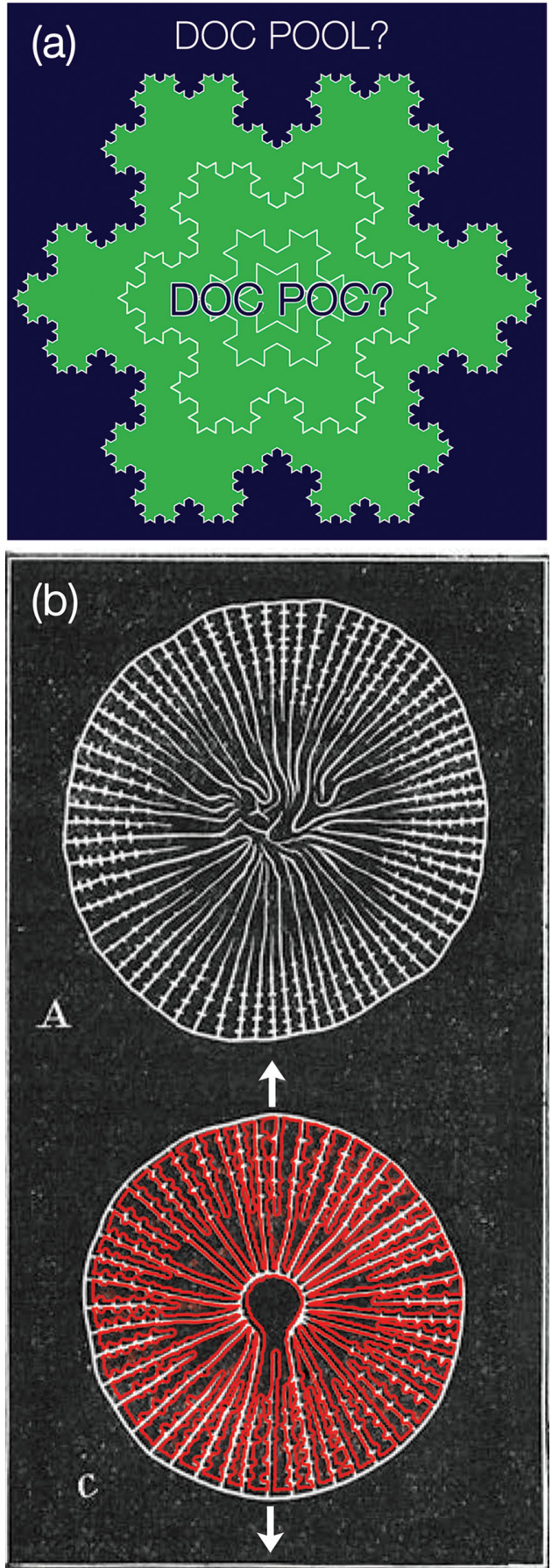

Fig. 8. Cartoons aimed at illustrating the high surface to area relationships of (a) epidermal cross-sections of rangeomorphs and (b) Devonian rugose corals. The nested curves in (a) are known as 'Koch snowflakes'; they are produced by duplications and rotations of a Koch curve (McCartney, 2021). They simulate the increase in complexity with size displayed by rangeomorph fronds during growth (Narbonne, 2004b). The green area represents the interior of the largest shape, which might have contained and processed dissolved and particulate carbon (DOC, POC). Under the DOC POOL hypothesis, food is absorbed directly from ocean water (Laflamme et al. 2009); the DOC POC hypothesis assumes that food was taken in and processed internally (Butterfield, 2020). (b) Drawings of two transverse sections of the rugose corals (A) Heliophyllum and (C) Crepidophyllum illustrate how secondorder ridges on major and minor carinate septa increase the area available for digestion by the gastrodermis (red). The directive axis of Crepidophyllum is indicated by arrows; this key-hole coral is shown in what was standard rugose coral orientation but should be rotated through $180^{\circ}$ for comparison with other anthozoans (Oliver, 1980). From Nicholson (1878), reproduced with permission from http://www. tandfonline.com 
epithelium covering their carinate or 'yard-arm' septa (Fig. 8b), serve as possible analogues for Butterfield's DOC POC mode. The ultimate origin of these postulated dispersed and degraded food resources may be provided by evidence from biomarkers (Bobrovskiy et al. 2020). However, the high density of substrate occupation by some frondose taxa $\left(200-1000 \mathrm{~m}^{-2}\right.$; Ivantsov, 2016) raises questions about supply. Another worry is the metabolic cost of keeping sizeable fronds inflated if Butterfield's (2020) DOC POC hypothesis is correct.

Another insight into the nutrition of Ediacaran organisms may come from the stunning report of abundant derivatives of cholesterol in coalified cadavers of Dickinsonia at a White Sea locality (Bobrovskiy et al. 2018). Cholesterol is a molecule that stiffens the membranes of eukaryotic cells. It is the dominant sterol in metazoans but is found in lesser amounts in other eukaryotes, most notably red algae (Brocks et al. 2017). In an adult human, cholesterol forms about $0.33 \%$ of total body weight so the amount present in any Dickinsonia carcass is likely to have been $<1 \%$. In herbivores, all of the cholesterol may be assumed to have been produced in situ, but omnivores and carnivores acquire significant amounts via their diets. Thus, the biomarkers found in Dickinsonia have some potential for understanding both its affiliation and its metabolism. However, any metabolic interpretation is complicated by what happens to the biomolecules following excretion, ingestion, death, burial and diagenesis. In Dickinsonia, the most abundant fossil steroids (steranes) are $5-\beta$ cholestane (sometimes known as coprostane) and its monoaromatic equivalents. This is surprising because most cholesterol is converted abiologically into 5- $\alpha$ cholestane, which is more stable and retains the trans stereochemistry of cholesterol and other natural steroids, unlike coprostane. Diagenetic isomerization normally drives the $5-\beta / 5-\alpha$ ratio towards an equilibrium value of $\sim 0.65$, so ratios as high as 5.5 in the White Sea Dickinsonia compressions require explanation (Bobrovskiy et al. 2018).

In humans and some other animals, anaerobic bacteria can convert cholesterol in the gut into coprostanol - which dehydrates to coprostane - either directly or via intermediates (Kriaa et al. 2019). If this is what caused the elevated $5-\beta / 5-\alpha$ cholestane ratios in Dickinsonia, how did obligate anaerobes gain access to cholesterol? If Dickinsonia had a gut and digestive system (Ivantsov, 2011), cholesterol is unlikely to have been part of the diet as the only environmentally available sterol seems to have been stigmasterol from green algae and unicellular heterotrophs (Bobrovskiy et al. 2018, 2020). Most of the cholesterol in Dickinsonia must have come from its tissues and it is therefore necessary to implicate anaerobes in the decay process, something not seen in younger forensic, archaeological or palaeontological contexts (Melendez et al. 2013; von der Lühe et al. 2018). However, this was Bobrovskiy et al.'s (2018) preferred explanation for the elevated $5-\beta / 5-\alpha$ ratios.

Bobrovskiy et al. (2020) pointed out that unicellular eukaryotes are a far better food source for early animals than are bacteria and suggested that the availability of high nutritional quality algal biomass may have triggered the Ediacaran radiation of metazoans. The fact that algal stigmasterols were not found in Dickinsonia may perhaps be explained if the unicellular eukaryotes were digested intracellularly rather than being incorporated into an alimentary canal system; shrimp fed on algal sterols excrete them 'qualitatively and quantitatively' (Bradshaw et al. 1990). The same logic could be applied to explain the dearth of bacterial hopanes in Dickinsonia. Hopanes are the carbon skeletons of hopanoids, which some bacteria use instead of steroids to stiffen their cell membranes; the hopane/sterane ratio of the fossils is $\sim 0.5$ (Bobrovskiy et al. 2018, table S3) compared with the enclosing sediments, which have a ratio of $\sim 3$ (Bobrovskiy et al. 2020, table S1). Thus, it seems that the biomarker evidence supports a lifestyle based on poriferanstyle phagocytosis rather than bilaterian extracellular digestion (Steinmetz, 2019); the former would destroy membrane molecules cell-by-cell soon after ingestion (see also Mcllroy et al. 2021).

The other principal hypothesis for vendobiont nutrition, endosymbiosis, may also be examined from the biomarker perspective. If Dickinsonia had been packed full of bacterial chemosymbionts like the trophosome of the vent worm Riftia pachyptila (Jones, 1981; Bright \& Sorgo, 2003), then their presence should be reflected in the hopane/sterane ratio, which seems not to be the case. However, if the endosymbionts were photoautotrophs like coral zooxanthellae, then their potential biosignatures may depend both on their nature and their abundance. Nevertheless, there is no indication from the biomarkers that Dickinsonia housed any kind of endosymbiont. Thus, it is most likely that Dickinsonia was a phagocytic ingester of prokaryotes and/or microscopic eukaryotes. If Bobrovskiy et al. (2020) are correct in their supposition that eukaryotes were the principal food source, then there are two possible supply pathways: planktonic green algae (Bobrovskiy et al. 2020) or benthic members of the meiofauna (Deline et al. 2018). How either kinds of organisms could be captured and taken in remains a mystery, but placozoan-like grazing on cyanobacterial mats (Sperling \& Vinther, 2010) is equally difficult to envisage. To paraphrase Ellis Yochelson (1928-2006), Quo vadis Dickinsonia? On the other hand, Ivantsov \& Zakrevskaya (2021b) have made a compelling case for planktotrophy and dorsal ciliary tract feeding in the Trilobozoa.

\section{4.d. Could Ediacaran animals move?}

A number of resting and movement traces have been attributed to Ediacaran organisms, but two kinds stand out: (1) overlapping resting traces attributed to movements made by individuals of Dickinsonia and Yorgia Ivantsov, 1999; (2) scratch marks (Kimberichnus Ivantsov, 2013) that are frequently associated with body fossils of Kimberella Wade, $1972 b$ (Ivantsov, 2009, 2013; Gehling et al. 2014). For the purpose of this discussion, I assume that both were produced by the organisms during life rather than being the result of environment-driven transport (McIlroy et al. 2009), given their taxonomic specificity. So the question is, was this by ciliary gliding (Martin, 1978), amoeboid crawling (Bond \& Harris, 1988; Arendt et al. 2015; Brunet \& King, 2017) or muscular motion, the three energetic methods of movement available to animals? My money is on the first for Dickinsonia and Yorgia; for Kimberichnus, it is more important to decide whether it was all or only some of the animal that was moving. We can say 'animal' more comfortably here because motility is one feature that helps to distinguish animals from all other kinds of megascopic life.

Living multicellular choanoflagellates use the muscle protein myosin for movement (Brunet et al. 2019). They can invert a cup-shaped 'colony' so that the collar cells can face inwards or outwards. And some sponges can move, albeit slowly and inefficiently (Bond \& Harris, 1988). If we think of life at the turn of the eon, being able to move was about as valuable a thing as anyone could imagine. Hyoliths, for example, seem to have evolved oar-like calcareous poles (helens) in order to be able to move a little (Runnegar et al. 1975; Martí Mus et al. 2014). Moving first by cellular processes, especially ciliary gliding, could have been the first step towards animal mobility. 
If the Dickinsonia and Yorgia footprints are locomotion trails, then it is striking that they are unidirectional in a way that conforms to the traditionally assumed anterior-posterior axis of the body (Glaessner \& Wade, 1966; Runnegar, 1982). What was the motive of this unidirectional motion - best shown on the 1T-NA surface at Nilpena as documented by Evans et al. (2019) - and how was it specified? It may be useful to think of minimal requirements such as navigation by solar tracking and photoreceptors no more complicated than flatworm eyespots. Even slime moulds display some phototaxis (Bonner \& Lamont, 2005).

Although passive transport by bottom currents seems unlikely to have produced the serial footprints of Dickinsonia and Yorgia, there is at least one good example of probable passive transport, the holotype of $D$. tenuis, which overlies the sand-filled stem of a felled Arborea that retains both the circular holdfast and the lower branches of the frond (Glaessner \& Wade, 1966, pl. 103, fig. 1).

\section{4.e. What was the composition of the tough organic integument?}

There are two approaches to this question, phylogenetic and taphonomic. If, for example, Dickinsonia was an annelid then its body wall should have been constructed from a chitinous and collagenous cuticle strengthened by circular and longitudinal muscles and connective tissue. Similarly, if Charnia and Charniodiscus were coelenterates, their body walls should have been composed of collagenous mesogloea sandwiched between inner and outer layers of epithelial cells. Alternatively, the preservation of the fossils themselves might suggest that they were made from a leathery (collagenous) material, plant-like biopolymers or something else.

With characteristic perceptiveness, Seilacher (1989) described the vendozoan integument as flexible but also malleable, watertight yet permeable, and cuticular but expandable during growth. Noting that the integument of Ernietta was both flexible and elastic, Dzik (1999) concluded that it must have been composed of collagen and served, like the myosepta of cephalochordates, to enclose the muscle blocks of a hydrostatic skeleton. Although collagenous macromolecular structures are sometimes preserved, most notably in graptolite periderm (Runnegar, 1986), they are not chemically proteins, which disappear swiftly unless encased in mineral skeletons. So, although we know a good deal about the biochemical components of the membranes of the cells of Dickinsonia (Bobrovskiy et al. 2018), there is as yet no ultrastructural or chemical evidence for the nature of the body wall of any Ediacaran soft-bodied organism.

\section{Some comments on key taxa: Pteridinium, Ernietta, Dickinsonia, Arborea, Kimberella}

\section{5.a. Pteridinium Gürich, 1933}

Pteridinium is an exemplar of the Nama association, in that it is a foliated organism formed of three quilted vanes and is commonly preserved in three dimensions within sandstone beds (Richter, 1955; Glaessner \& Wade, 1966; Pflug, 1970; Jenkins, 1992; Narbonne et al. 1997; Dzik, 1999; Meyer et al. 2014b). It has been reconstructed in several different ways but its affinities and mode of life remain controversial. One prominent hypothesis - that Pteridinium was canoe-shaped and lived partly or wholly within the sediment in which it is found (Pflug, 1970; Grazhdankin \& Seilacher, 2002) - is almost certainly incorrect. It is most likely that
Pteridinium was the principal and perhaps propagative part of an upright organism that is nearly always preserved as a transported, deformed and pliable shroud. Its early life stage and attachment structure, if any, may not have been identified. Given its threefold symmetry, it is even possible that Pteridinium is the dispersed frond of one or more coeval trilobozoan discs, such as Tribrachidium Glaessner in Glaessner \& Daily, 1959 or Rugoconites Glaessner \& Wade, 1966.

Gürich (1933) had only two inferior specimens of Pteridinium to work with and did not discover the third vane. Richter (1955) had much better material but came to the strange conclusion that specimens with three vanes were caused by the close packing of left- and right-handed two-vaned individuals, which were twinned like crystals during growth from the sea floor. Nevertheless, Richter did have a clear view of the mode of life and taphonomy of Pteridinium, imagining it to have been rooted in unconsolidated sediment, grown gregariously and, like kelp forests, flexed with the currents and the tides. His choice of a gorgoniid octocoral the angular sea whip, Pterogorgia anceps - as the closest living analogue was based on its commonly Y-shaped cross-section plus the fact that gorgoniids are readily rooted within soft substrates whereas kelps normally require rocky or stony bottoms. Richter also concluded that the fronds of Pteridinium were tall and tapered slowly from a maximum measured width of $16 \mathrm{~cm}$. The longest vane available to him was $37 \mathrm{~cm}$, comparable to the longest incomplete individual $(41.5 \mathrm{~cm})$ reported by Grazhdankin \& Seilacher (2002), so fronds of Pteridinium simplex could have been a sizeable fraction of a metre in height. However, very few specimens of P. simplex show a close approach to the end of a frond (Fig. 9), and as no termination has been reported, it is possible that growth continued for more than a metre.

The unipolarity of Pteridinium was confirmed by the discovery of additional species, most notably $P$. carolinaense, famously first described as a trilobite (St Jean, 1973). However, Richter had deduced it from the curvature of the vane quilts, which are convex in the apical direction. The 3D shape of the termination has been less well understood, as two end-member hypotheses illustrate. In the 'canoe' model for Pteridinium (Pflug, 1970; Buss \& Seilacher, 1994; Crimes \& Fedonkin, 1996; Grazhdankin \& Seilacher, 2002; Meyer et al. 2014a; Droser et al. 2017), two of the vanes form the prows and hull of a canoe-shaped organism that was at least partially buried in the sediment during life; the third vane had the form of a retracted keel running down the length of the canoe. Even more strikingly, Grazhdankin and Seilacher believed that one end of the canoe could reverse direction during extensional growth and that the keel vane of the older, deeper part of the organism could become one of the hull vanes of the younger, shallower section (Grazhdankin \& Seilacher, 2002, text-fig. 5C). Additional speculations, not considered here, were interpenetrative growth, where one individual might grow through a pre-existing one without disrupting either, and growth solely within the pore space of the enclosing sand (Crimes \& Fedonkin, 1996).

The alternative end-member model for vane orientation is best illustrated by reconstructions of Swartpuntia germsi (Narbonne et al. 1997). Although originally described as having four or more vanes, Swartpuntia probably had only three (Narbonne, 1998, fig. 1B) and possibly no stalk or holdfast. As such, it is close to Pteridinium, perhaps even congeneric, if you happen to be a lumper rather than a splitter. Because Swartpuntia has always been considered to be an upright organism, its vanes are thought to have been flat and equally spaced radially. The same configuration may be true for Pteridinium, as Jenkins (1992) surmised. 


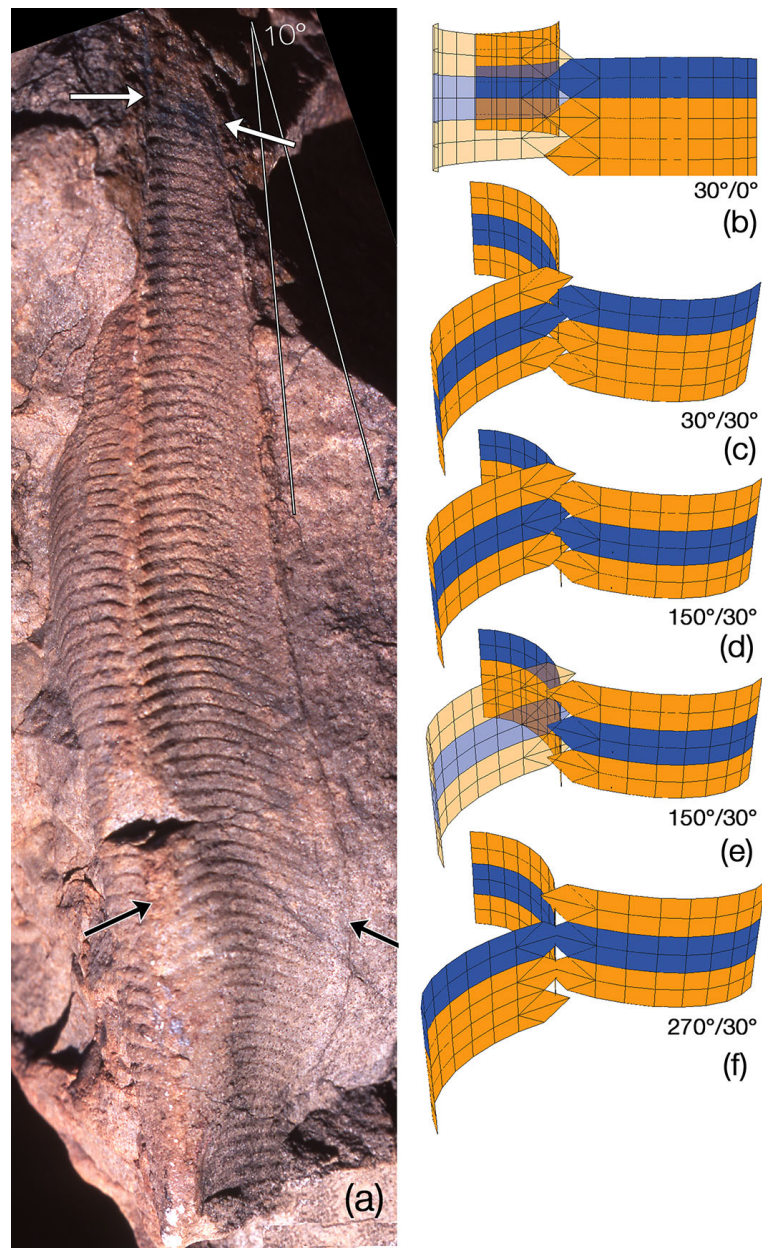

Fig. 9. Geometry of Pteridinium simplex. (a) Exceptional specimen showing tapered approach to the distal end of the organism (top) and measured widths of the righthand vane between upper arrows $(13 \mathrm{~mm})$ and lower arrows $(24 \mathrm{~mm})$; unnumbered specimen in the private collection of Wilfried Erni, Plateau Farm, Aus district, Namibia photographed on site in 1996; previously illustrated by Laflamme \& Narbonne (2008, fig. 5.5). (b-f) Differently rotated views of part of a model for the orientation and interdigitation of the three vanes. Vanes are modelled as flat curved surfaces set at $120^{\circ}$ to each other. Each set of vanes is offset by one module in two of the three intersections (c), (d), (e), but the ends of the modules are opposite each other in the third position (b), (f). Angles are rotations about the axis of the model and tilt with respect to the model. One set of modules is shown in blue for clarity.

The mode of articulation of the quilts of the vanes has also been interpreted in different ways. Ideally, three equally spaced, equal size vanes would be opposite each other across the axis or be offset from each other by an equal amount. In theory, a one third offset of each quilt with respect to the quilts of the adjacent vane, taken in order, would result in [123] or [132] glide symmetries, where 1,2 and 3 denote the individual vanes (Tojo et al. 2007). This was the design adopted by Grazhdankin \& Seilacher (2002, text-fig. $6 \mathrm{H})$ for their canoe keel. However, Pflug (1970), Jenkins (1992) and others have inferred more elaborate architectures, which result in some pairs of vanes being articulated in an elementary zig-zag fashion (Tojo et al. 2007, fig. 4A2-A3). In other orientations, there may also be a chain of matrix-filled beads between the proximal edges of the two visible vanes (Grazhdankin \& Seilacher, 2002, text-fig. 6F; Pflug, 1970, text-fig. 3E, pl. 21, fig. 2, text-fig. 8D, pl. 22, fig. 1). These are the structures that led Jenkins (1992) erroneously to reconstruct Pteridinium with two layers of tubular quilts per vane, but they are readily explained as ends of quilts of the third vane, which are visible through apertures in the seam (Figs 9, 10). Thus, Pteridinium did not have perfect three-fold symmetry; rather, it had a best approximation to three-fold symmetry, given the constructional constraints for packing tubular quilts in three dimensions. Achieving the ideal geometry of perfect symmetry (Tojo et al. 2007) was probably beyond the developmental capabilities of this organism.

\section{5.b. Ernietta Pflug, 1966}

Ernietta (Fig. 3) was a bag-shaped organism constructed from the same kind of modules as Pteridinium (Pflug, 1970, 1972b; Jenkins et al. 1981; Dzik, 1999; Elliott et al. 2016; Ivantsov et al. 2016) and probably Phyllozoon (Gehling \& Runnegar, 2021). Reconstructions by Jenkins (in Jenkins et al. 1981) and Ivantsov et al. (2019c) are remarkably similar and perhaps both incorrect in the same two interconnected ways. It is unequivocal that some specimens from Aar show evidence for walls made of more than one layer of tubular modules (Jenkins et al. 1981; Elliott et al. 2016) and that many specimens have a constriction at their waist, but I would argue that these two phenomena may be site-specific and causally connected. The constrictions may be due to injury and truncation during a storm surge (Jenkins, 1985, fig. 1) and the duplicate walls to secondary regrowth of the truncated parts. An analogous situation is seen in cohorts of Dickinsonia menneri from the White Sea (Ivantsov et al. 2020). If true, this would make Ernietta plateauensis a far simpler organism than previously thought and one that was capable of vegetative regrowth. All known specimens from Nevada show no trace of these features (Smith et al. 2017). Furthermore, Ernietta from Nevada (Smith et al. 2017, fig. 3d; Hall et al. 2020, fig. 1b) and at least one specimen from Namibia (Narbonne, $2004 a$, fig. 4 b) have modules that terminate distally in pointed tips (Fig. 3a) well separated by open spaces, rather different from the situation seen in the two reconstructions. This is an indication that the modules were independent units that merged during growth rather than subdivisions of the whole (Gehling \& Runnegar, 2021). Seilacher (1992) had stipulated the opposite when characterizing the Vendobionta.

\section{5.c. Dickinsonia Sprigg, 1947}

The type species, Dickinsonia costata Sprigg, 1947, is an iconic Ediacaran fossil, a core member of the Vendozoa (Seilacher, 1989) and a candidate bilaterian animal (Gold et al. 2015). Seen in plan view as it is presumed to have lived on the sea floor, D. costata is almost circular (Fig. 4b), bilaterally symmetrical and differentiated into a proximal or 'anterior' end with a single undivided module lying across the midline and a distal or 'posterior' end, from which growth proceeds (Ivantsov et al. 2020). Suggestions that growth might have proceeded in the opposite direction (Hoekzema et al. 2017; Dunn et al. 2018) were falsified recently by the discovery of a cohort of individuals of D. cf. menneri Keller, 1976 in Keller \& Fedonkin, 1976, several of which had regenerated the 'posterior' end of the body by growing new modules following non-lethal loss (Fig. 4a; Ivantsov et al. 2020). However, closer inspection of the outline of D. costata reveals that it may be better approximated by the curve known as a cardioid rather than a circle or ellipse, a shape that has not been replicated in any of the proposed growth models. It is also a propensity taken to extremes by Andiva Fedonkin, 2002, where the site of 'terminal addition' (Gold et al. 2015) has moved so far forward as to be in the anterior half of the body (Ivantsov, 2007, pl. 1, fig. 6). 

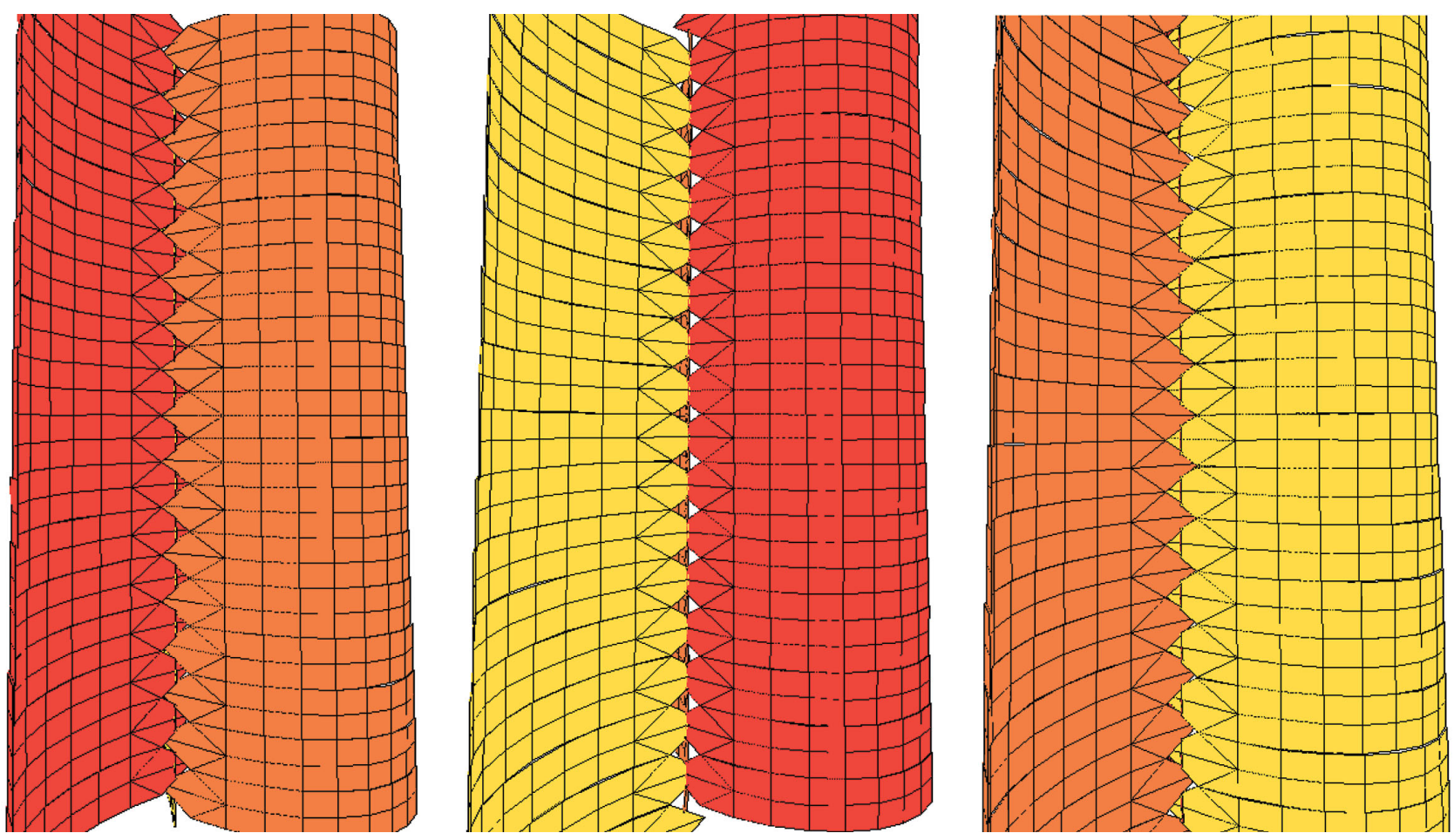

Fig. 10. Toy $3 \mathrm{D}$ model of part of a frond of Pteridinium simplex rotated through $120^{\circ}$ and $240^{\circ}$ to show views of the intersections between adjacent pairs of vanes. Note that in the left and right images the sutures between modules are offset in a zig-zag fashion, whereas in the middle image the modules of adjacent vanes are opposite one another and there is a series of rhomboidal gaps along the axis, as found in a number of fossils.

As is well known, the body of Dickinsonia costata was constructed from segments, isomers, units or modules, which appeared at an unresolvable size at the 'posterior' end and continued to grow and change shape during the life of the animal (Runnegar, 1982; Evans et al. 2017). This alone is a feature of animals rather than plants, kelps or fungi. The modules are defined by raised ridges on the upper surface of specimens preserved in the typical way (concave hyporelief), both in South Australia and Russia, and by grooves in the impressions of lower surfaces (Fig. 4b, c; Seilacher, 1989, fig. 5). In large specimens, such as the frequently illustrated $D$. costata from Brachina Gorge (Wade, 1972a, pl. 5, figs 1, 2; Runnegar, 1982, figs 4, 5; Seilacher, 1989, figs 3, 5; Retallack, 2007, fig. 1A; Budd \& Jensen, 2017, fig. 4E) or the $1 \mathrm{~m}$ sized D. rex Jenkins, 1992 (Gehling et al. 2005, fig. 4), the peripheral ends of the ridges are expanded and imbricated in ways that imply that the module walls were stiff like the 'struts of a glider plane wing' (Fig. 4a; Seilacher, 1989, p. 236).

This brings us to the contentious matter of whether or not Dickinsonia exhibits glide symmetry (Fig. 4a, b). The Australian position is 'no', based on a large cohort of small individuals of D. costata from a single surface in Crisp Gorge, central Flinders Ranges (Gold et al. 2015; Reid et al. 2017) as well as numerous specimens from other localities. In contrast, Russian workers identify glide symmetry in all species of Dickinsonia, including D. menneri and D. costata (Ivantsov, 2007; Ivantsov et al. 2020). To some extent, this difference of opinion is hypothesis driven, but it is clear that other members of the same 'orphan plesion', the Proarticulata, clearly show this property. Perhaps the most convincing example is the specimen of Andiva ivantsovi Fedonkin, 2002 illustrated by Dunn et al. (2018, fig. 4), where the insertion of new modules is shown to have occurred alternately on left and right sides of the body. It is time for Australians to acknowledge that proarticulate glide symmetry is a widespread feature of this putative clade and for Russians to admit that some members of the group do not display it.

Much has been written about the internal anatomy of Dickinsonia, starting with Glaessner and Wade's discovery of the casts of intestinal caeca on a single specimen of $D$. costata from Ediacara (Glaessner \& Wade, 1966, pl. 101, fig. 4). As confirmation from other specimens failed to materialize, this observation was either disregarded (Runnegar, 1982) or embellished (Jenkins, 1992, fig. 13). Nevertheless, the elevated axial ridge or pair of ridges that are found on many Australian and Russian specimens have been interpreted as evidence for a sediment-filled gut (Wade, 1972a; Runnegar, 1982; Ivantsov, 2004), which terminated at the posterior end of the ' 0 module' (Fig. 4a; Runnegar, 1982, fig. 1C, F; Gehling et al. 2005, fig. 4a; Sperling \& Vinther, 2010, fig. 1A; Gold et al. 2015, fig. 1D; Evans et al. 2017, fig. 3b; Hoekzema et al. 2017, fig. 1). According to the proarticulate hypothesis, the 'gut' consisted of two parallel tubes on either side of an axial partition against which the left and right half modules or 'isomeres' abutted (Ivantsov, 2011, fig. 6). The prominence and yet narrowness of this feature in some specimens of Dickinsonia (Gehling et al. 2005, fig. 4; Ivantsov, 2007, pl. 1, fig. 1), Yorgia (Ivantsov, 1999, pl. 1, fig. 4; Evans et al. 2019, fig. 12d) and Andiva (Ivantsov, 2007, pl. 1, fig. 6) make the gut interpretation improbable; a constructional or some other function seems more likely. Particularly telling is the remarkable imprint (Epibaion axiferus) of the putative lower surface of Dickinsonia cf. tenuis (Ivantsov \& Malakhovskaya, 2002, pl. 2, fig. 3; Ivantsov, 2011, pl. 2, fig. 1; Ivantsov, 2013, pl. 1, fig. 1), which shows the left and right side modules joined to a well-defined axis. It is hard to imagine how an internal organ could be expressed so crisply 
externally, although it may have been in a similarly axial position. However, Ivantsov's (2011) concept of a median septum with longitudinal 'feeding channels' on either side makes more sense for the numerous specimens that have elevated ridges on either side of a depressed midline, as is typical of Dickinsonia lissa Wade, 1972a (Runnegar, 1982, fig. 1A-B; Ivantsov, 2007, pl. 1, fig. 1). Perhaps the axial ridge is nothing more than a topographic high produced during burial by fluid flow from the modules; its prominence in $D$. lissa may be owing to the fact that the modules are exceptionally narrow and thus constrained all body fluids to move in an axial direction.

Three discoveries made at the White Sea have allowed more elaborate reconstructions to be made of Dickinsonia's soft parts. First, several specimens of Dickinsonia cf. lissa with complexly corrugated surfaces were discovered at Zimnie Gory (Dzik \& Ivantsov, 2002). The corrugations, which radiate and branch towards the 'anterior' direction, were thought to overlie a straight gut and its diverticula as best shown in a cutaway perspective view drawn by Dzik (2003, fig. 6). However, it is notable that Dzik's drawings show no trace of glide symmetry in the internal organs, an anomaly corrected by Ivantsov (2004, fig. 6); the specimens themselves are ambiguous in this respect. Furthermore, although the corrugations superficially resemble the isomers of other White Sea proarticulates such as Vendia rachiata Ivantsov, 2004, it was necessary for Budd \& Jensen (2017, fig. 4) to rotate one of the corrugated specimens of $D$. cf. lissa through $180^{\circ}$ to make the visual comparison meaningful. The only other Ediacaran fossil with comparable corrugations is the holotype of Chondroplon bilobatum, which comes from a mass flow sandstone at Ediacara, and thus is preserved in the Nama manner (Wade, 1971). Hofmann (1988) reinterpreted Chondroplon as a deformed Dickinsonia, a view that was adopted by Dzik \& Ivantsov (2002). However, it is difficult to exclude the possibility that the corrugations in both taxa are taphonomic effects caused by contractions parallel to the trend of the modules rather than crinkles above incompressible organs (Budd \& Jensen, 2017).

The two other discoveries are feathery and beaded structures within modules of Yorgia and Dickinsonia (Ivantsov, 2013, pl. 1, figs 3,4 ) and a remarkable incomplete specimen of Dickinsonia cf. tenuis, in which the tubular modules were apparently filled with fine sediment (Ivantsov, 2011, pl. 1, fig. 3). Modules of undescribed specimens of D. rex Jenkins, 1992 from Nilpena were also filled in this way (J. G. Gehling, pers. comm.). Taken together, these observations tell us little about the internal anatomy of Dickinsonia and the other proarticulates. At best, Seilacher's characterization of them as fluid-filled 'pneus' may serve as the current null hypothesis.

\section{5.d. Arborea Glaessner \& Wade, 1966}

Ford's chimera of Charnia and Charniodiscus (Fig. 2) serves as a graphical abstract for the Arboreomorpha and Rangeomorpha, two putatively monophyletic clades that may together constitute a monophyletic or paraphyletic group. The tortuous taxonomic trajectory of Arborea reminds us of the obvious similarities yet important differences between the arboreomorphs and rangeomorphs, which have been carefully and thoroughly explored by Canadian and British teams led by Guy Narbonne and Martin Brasier (1947-2014), respectively, over the past several decades.

The first collection of fronds from Ediacara included several slabs of Arborea and one of Charnia. All were referred to Gürich's genus Rangea, but in an addendum added after Ford's
(1958) article was published, Glaessner noted that one was a Charnia not a Rangea (Glaessner \& Daily, 1959). By 1960, all of the Ediacaran fronds had become Charnia (Fig. 2; Glaessner, 1962), but in 1966 Charnia had gone and all of the fronds were now split between two new species of Rangea and the type species of the new genus, Arborea (Glaessner \& Wade, 1966). The original example of Charnia was rescued by Germs (Germs, 1973), who named it Glaessnerina, now a junior synonym of Charnia. Then in 1978, Jenkins \& Gehling (1978) synonymized Arborea with Charniodiscus and she remained in limbo until resurrected from obscurity (Laflamme et al. 2018; Dunn et al. 2019; Wang et al. 2020). All of this equivocation argues for a biological relationship between Charnia and Arborea that is significant at the scale of this review.

The anatomy of Charnia masoni and its relatives have been beautifully revealed by numerous studies of occurrences in Avalonian England and Newfoundland (Narbonne, 2004b; Antcliffe \& Brasier, 2006; Gehling \& Narbonne, 2007; Laflamme et al. 2007, 2012; Hofmann et al. 2008; Narbonne et al. 2009; Brasier et al. 2012; McIlroy et al. 2020). Rangeomorphs are frondose taxa that maximized surface area via fractal growth (Fig. 8). The most obvious links to the Arboreomorpha are their similar body forms and discoidal holdfasts, at least in some members of each group. I treat them as a paraphyletic grade for the sake of simplicity (Fig. 12); cladistic analyses have recovered the Erniettomorpha as sister of the Rangeomorpha (Dececchi et al. 2017; Hoyal Cuthill \& Han, 2018), and it is plausible to refer all three groups to Pflug's Petalonamae. However, major differences in construction of the three groups, summarized in the first five characters of Dececchi et al.'s data matrix (modular or not, branching or not, tubular modules or not, fractal construction or not, differentiated elements or not), also permit the following relationship: (Erniettomorpha (Arboreomorpha, Rangeomorpha)).

\section{5.e. Kimberella Wade, 1972b}

When Glaessner \& Wade (1966) first described Kimberella (as Kimberia quadrata), Sprigg's jellyfish hypothesis was state of the art, and so they doubled the visible bilateral symmetry on the assumption that they were looking at a crushed hydrozoan or cubozoan medusa. Wade (1972b) extended this way of thinking but was unwilling to refer Kimberella to either the Hydrozoa or the Cubozoa, preferring to regard it as something like a stem member of one or both of these groups (Glaessner, 1984, fig. 3.2). However, Jenkins (1984) confidently considered Kimberella to be ancestral to the living box jellyfish and even speculated that cubozoans refined and perfected their potent venom over an eon of evolution. One reason this jellyfish hypothesis seemed to work so well is that almost every Australian specimen of Kimberella has a wellrounded and clearly formed end (the bell) and fades out at the other end into what may be thought of as tentacles.

The breakthrough with Kimberella came with the discovery of much better material in Russia and its analysis by Fedonkin \& Waggoner (1997). Unfortunately, although the bilateral symmetry seems clear, there was and still is no other character that could identify Kimberella as a mollusc or even a bilaterian animal. However, sets of paired scratch marks, found in fan-shaped arrays on bed bases and interpreted as possible arthropod scratch marks, had been previously illustrated by Gehling (1991, pl. 6, fig. 3) and their producer adventurously reconstructed by Jenkins (1992, fig. 10). The association of these trace fossils, now known as Kimberichnus teruzzi (Ivantsov, 2013; Gehling et al. 2014), has 
firmed up the idea that Kimberella was a bilaterian metazoan (Fedonkin et al. 2007; Ivantsov, 2009, 2013).

There are, however, some difficulties with attributing the traces to Kimberella. The body fossils obviously pre-date the deposition of the event bed that buried them, but the time of formation of the traces is more uncertain. Given their similarity to Monomorphichnus Crimes, 1970 (Jenkins, 1992, 1995) - one of Seilacher's (2007) trilobite 'deep undertraces' - they could have been made after the storm sand was deposited. That could explain how Kimberichnus was superimposed on an Aspidella holdfast (Ivantsov et al. 2020, fig. 1) and a Phyllozoon frond (Gehling \& Runnegar, 2021, fig. S3a); undertraces are constructed with the soft sand in place. The alternative hypothesis, that the traces were made by mining an exposed mat surface, requires the paired scratches to remain open for extended periods of time (e.g. Gehling et al. 2014, fig. 6), a problem perhaps solved by Budd \& Jensen (2017, p. 458), who concluded that the sharpness of the scratches shows 'that they were not formed in the mat but rather in the sediment underlying the mat.' However, this is unlikely to be true for the Kimberichnus found in Bathtub Gorge, South Australia, where the underlying bed has a coarse sugary top that contrasts with the fine base of the overlying event bed (Gehling \& Runnegar, 2021). The production of Kimberichnus needs additional investigation.

The most striking feature of the anatomy of Kimberella is the so-called 'crenellated zone', which encircles most of the body and generally lies inboard of a well-defined rim (Fedonkin \& Waggoner, 1997). The preservation of this feature varies greatly from non-existent to ladder-like in expanded specimens. It has been reconstructed as a ruff-like extensible mantle (Fedonkin \& Waggoner, 1997, fig. 2b; Fedonkin et al. 2007, fig. 23d), as the scalloped zone of a dorsal carapace (Ivantsov, 2013, 2017) and in the box jellyfish phase, as pouched gonads attached to radial canals (Wade, 1972b, text-fig. 6; Jenkins, 1984, text-fig. 2). The evidence for this crenellated zone being suspended above the sides of the body is slight and in many specimens, small and large, the crenellations extend to the rim. However, in those cases they look more like regularly arranged anticlinal ridges than ruff-like folds. Similar angular ridges are seen in specimens of Temnoxa molliuscula and Keretsa brutoni (Ivantsov, 2017; Ivantsov \& Zakrevskaya, 2021c), which like Kimberella, have a rounded larger terminus and a tentlike shape following compaction. Australian specimens of Keretsa and Kimberella are even more similar in these respects (Gehling, 2005, fig. 12K; Gehling et al. 2005, fig. 12).

There are many other well-characterized aspects of the anatomy of Kimberella, but it is the flat and probably muscular base that most obviously suggests an affinity with the Mollusca. However, extended specimens that are connected to fan-shaped arrays of Kimberichnus plausibly made by them, suggest alternative possibilities (Ivantsov, 2009; Gehling et al. 2014), one of which might be an animal of cnidarian grade. It is possible to regard Kimberella as some kind of foraging anemone, anchored by an aboral pedal disc and collecting food with a cuticularized oral apparatus that acted more like a rake than a pair of claws (Ivantsov, 2009). It may not have moved around much, if at all, operating more like a strip-mining dragline than a mechanical excavator (Gehling et al. 2014, fig. 9).

\section{Speculative discussion}

\section{6.a. Introduction}

Despite all of the research that has been accomplished over the past three quarters of a century and the dedicated contributions of many talented palaeobiologists, the presumed affinities of Ediacaran organisms have, on average, hovered continuously around the coelenterate grade, although there has been significant stemward slippage in recent years (Table 1 ). The only really positive assignments, such as Glaessner's Pennatulacea hypothesis, have been falsified, and the current approach of seeking ever more detailed and quantifiable knowledge (Laflamme et al. 2004; Evans et al. 2017; Hoekzema et al. 2017; Hoyal Cuthill \& Han, 2018) has not, as yet, led to startling outcomes. Perhaps the time is ripe for some speculative, even outlandish thinking. It may also be useful to review briefly previous ways of dealing with problematical fossils.

\section{6.b. Prior Problematica}

Palaeontologists have long been perplexed by problematical fossils, particularly by those with no obvious living counterparts (Bengtson, 1986). Famous examples include rudist bivalves (Skelton, 2018), graptolites (Mitchell et al. 2013), archaeocyaths (Rowland, 2001) and the phosphatic microfossil Microdictyon, which as the authors who named it noted, is 'shaped like a little net' (Bengtson et al. 1986). Of these conundrums, rudists were solved first by S. P Woodward, author of A Manual of the Mollusca (1851-1854), in a remarkably advanced article published even before brachiopods were removed from the phylum. Woodward's words resonate today despite his firm belief in Divine creation rather than Darwinian transmutation: 'In searching out the affinities of a problematic fossil shell, it is desirable to inquire, first, whether any similar, but less abnormal, forms occur in the same stratum with it, or in formations immediately older or newer. ... We think it may be shown, that, by a complete series of cognate forms, the Cretaceous Hippurites are connected with the Oolitic Dicerata and the Tertiary Chame.' (Woodward, 1855, p. 46). Thus, these strange coral-like bivalves (Fig. 11b) were confidently identified as a major extinct clade of the Bivalvia by the mid-nineteenth century (Skelton, 2018; Rineau et al. 2020).

Clarification of the affinities of graptolites followed another path. Roman Kozlowski's pre-Second World War discovery of extractable, three-dimensionally preserved colonies in Polish Ordovician limestones revealed the fine structure of the periderm to be formed of 'half rings' as in living pterobranchs (Fig. 11a; Kozlowski, 1947). The hemichordate hypothesis received a second boost when Towe \& Urbanek (1972) provided ultrastructural evidence that the graptolite periderm was composed of collagen rather than cellulose or chitin (Runnegar, 1986), and has been accepted ever since. In this case, it was new information from both the fossils and their living relatives that turned the tide.

Archaeocyaths (Fig. 11d) are another previously problematical group that was passed around phylogenetically speaking until the emergence of two mid-twentieth century hypotheses: an extinct phylum, the Archaeocyatha (Hill, 1964) or kingdom, the Archaeta (Zuhuravleva \& Myagkova, 1972); or an extinct sponge clade and grade. The second alternative is now mainstream; its acceptance required the SCUBA-enabled discovery of living aspiculate sclerosponges as analogues for archaeocyaths (Vacelet, 1985; Kruse, 1990; Rowland, 2001).

In contrast, Microdictyon (Fig. 11c) was one of the many small shelly fossils that fell out of early Cambrian carbonates dissolved slowly and laboriously in acetic acid (Bengtson et al. 1986). Speculations about its affinity and function were wide ranging and numerous, but the solution seemed absurd when it suddenly appeared. Stefan Bengtson and I were sitting together in a meeting at UCLA when he opened a letter from China that contained a 
Table 1. Chronology of taxonomic assignments to core members of the Ediacara biota. Note the stemward movement as time progresses. Cnidaria highlighted in grey

\begin{tabular}{|c|c|c|c|c|c|c|c|}
\hline Date & Taxon/Author & Arborea, Charniodiscus & Ediacaria, Cyclomedusa & Charnia, Rangea & Pteridinium, Ernietta & Dickinsonia, Yorgia & Kimberella, Keretsa \\
\hline 1946-1949 & Sprigg & algae & Cnidaria: Medusozoa & ? & & Cnidaria: Medusozoa & \\
\hline 1955 & Richter & & & ? & Cnidaria: Anthozoa & & \\
\hline 1955 & Harrington \& Moore & & & & & Cnidaria: Medusozoa & \\
\hline 1957 & Caster & & Cnidaria: Medusozoa & & & & \\
\hline $1957-1961$ & Glaessner & Cnidaria: Anthozoa & Cnidaria: Medusozoa & Cnidaria: Anthozoa & & Annelida: Sedentaria & \\
\hline 1958-1963 & Ford & algae & algae & algae & algae & & \\
\hline $1966-1972$ & Pflug & stem Metazoa? & & stem Metazoa? & stem Metazoa? & & \\
\hline $1966-1972$ & Glaessner \& Wade & Cnidaria: Anthozoa & Cnidaria: Medusozoa & Cnidaria: Anthozoa & Cnidaria: Anthozoa & Annelida: Sedentaria & Cnidaria: Medusozoa \\
\hline 1978 & Jenkins \& Gehling & Cnidaria: Anthozoa & & & & & \\
\hline 1983-1992 & Seilacher & stem Metazoa & stem Metazoa & stem Metazoa & stem Metazoa & stem Metazoa & \\
\hline 1981-1987 & Fedonkin & TG Metazoa & Cnidaria: Cyclozoa & TG Metazoa & TG Metazoa & stem Protostomia & Cnidaria: Medusozoa \\
\hline 1984-1990 & Jenkins & Cnidaria: Anthozoa & Cnidaria: Medusozoa & Cnidaria: Anthozoa & Cnidaria: Anthozoa & Annelida: Sedentaria & Cnidaria: Medusozoa \\
\hline 1992 & Valentine & & & & & stem Cnidaria? & \\
\hline 1991-1992 & Runnegar & Cnidaria: Anthozoa & Cnidaria: Medusozoa & Cnidaria: Anthozoa & & Annelida? & \\
\hline $1992+$ & Seilacher & TSAR: Alveolata & TSAR: Alveolata & TSAR: Alveolata & TSAR: Alveolata & TSAR: Alveolata & Mollusca: Gastropoda \\
\hline 1994 & Buss \& Seilacher & stem Cnidaria & stem Cnidaria & stem Cnidaria & stem Cnidaria & stem Cnidaria & \\
\hline $1994+$ & Retallack & & lichenized Fungi & & & lichenized Fungi & \\
\hline 1997 & Fedonkin \& Waggoner & & & & & & stem Protostomia \\
\hline 2006 & Zhang \& Reitner & & & & & Ctenophora & \\
\hline $2009+$ & Ivantsov & TG Metazoa & TG Metazoa & TG Metazoa & TG Metazoa & stem Protostomia & crown Protostomia \\
\hline 2017 & Budd \& Jensen & stem Eumetazoa & & stem Metazoa & & stem Eumetazoa & stem Bilateria \\
\hline 2017 & Cavalier-Smith & stem Metazoa & stem Metazoa & stem Metazoa & stem Metazoa & stem Metazoa & \\
\hline 2017 & Dufour \& Mcllroy & stem Eumetazoa & stem Eumetazoa & stem Eumetazoa & stem Eumetazoa & stem Eumetazoa & \\
\hline 2018 & Hoyal Cuthill \& Han & stem Eumetazoa & stem Eumetazoa & stem Eumetazoa & stem Eumetazoa & stem Eumetazoa & \\
\hline 2018 & Dunn, Liu \& Donoghue & & & stem Eumetazoa & & & stem Bilateria \\
\hline 2021 & Evans, Droser \& Erwin & & & & & stem Bilateria & crown Bilateria \\
\hline 2021 & This review & stem Eumetazoa & stem Eumetazoa & stem Eumetazoa & stem Eumetazoa & stem Bilateria? & stem Coelenterata? \\
\hline
\end{tabular}

TG - total group; TSAR - Telonemia + Stramenopila + Alveolata + Rhizaria. 
(a)

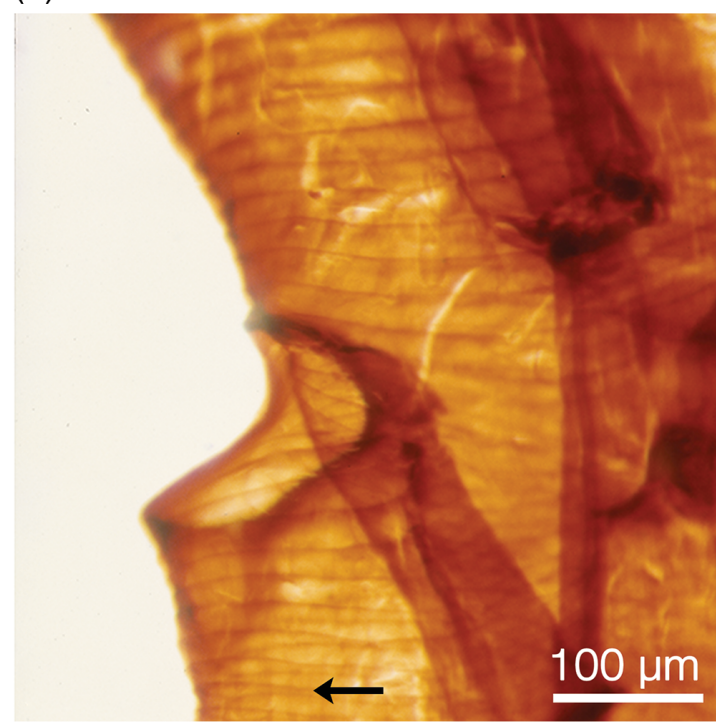

(c)

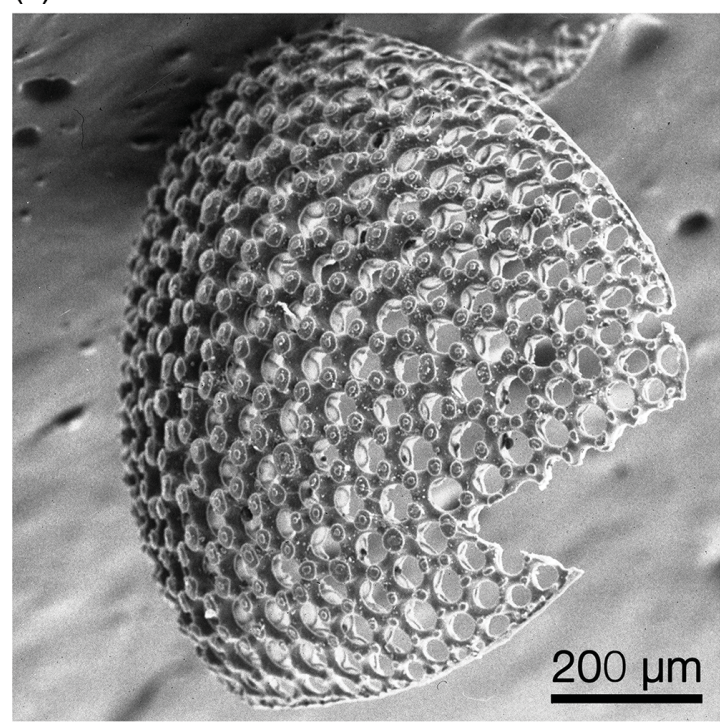

(b)

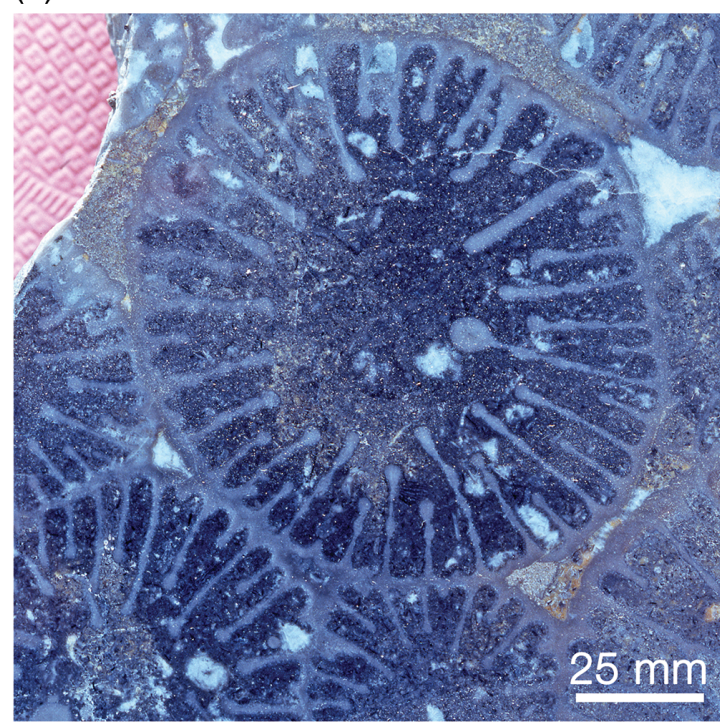

(d)

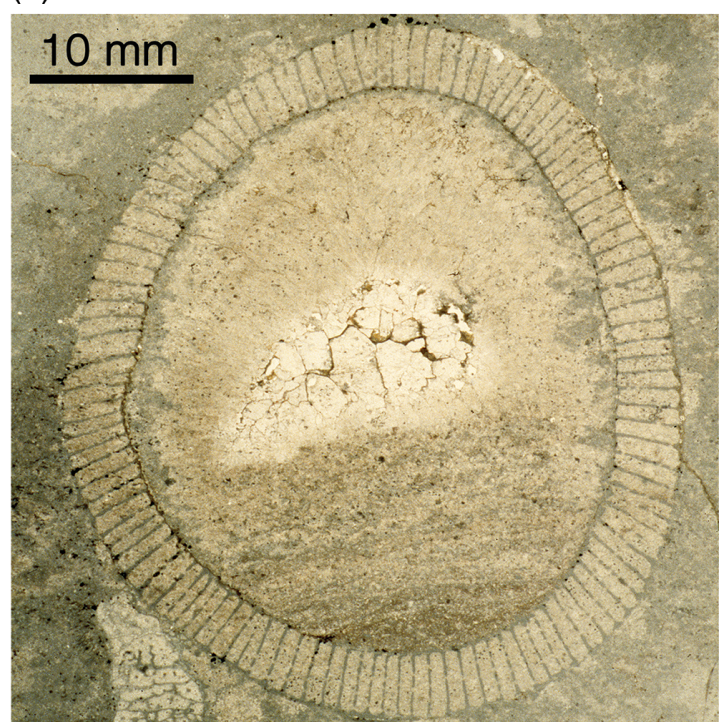

Fig. 11. Previously puzzling Problematica. (a) 3D preservation of Ordovician graptolite Amplexograptus maxwelli, Bromide Formation, Oklahoma, showing half-ring construction of periderm (arrow). (b) Coral-like Cretaceous rudist bivalve Barrettia monilifera, Florida Formation, Puerto Rico. (c) Phosphatic shoulder pad of Cambrian lobopod Microdictyon cf. robisoni, Gowers Formation, Queensland. (d) Transverse thin-section of Cambrian regular archaeocyath Loculicyathus alternus, Ajax Limestone, South Australia.

photograph of the Microdictyon animal from Chenjiang. We both began to laugh; no one could have imagined that Microdictyon was the shoulder pads of a lobopodian relative of Conway Morris's Hallucigenia. Some answers require new evidence rather than imagination.

Applying these lessons to the Ediacaran fossils may help find their place in the tree of life. Here are other guidelines, largely adapted from Dunn \& Liu (2019): (1) Know that all fossils must be connected to some branch of the extant tree of life; they will either be stem or crown members of their respective clades. (2) Work with the best current consensus tree based on phylogenetic information obtained from living organisms. (3) Assume that most early problematical fossils - orphan plesions - will be stem rather than crown members of their respective clades. (4) Avoid terminology that incorporates a preconceived worldview when naming clades. (5) Use data obtained from populations of individuals rather than individual examples whenever possible.

\section{6.c. Phylogenetics}

For a phylogenetic framework, I assume that a monophyletic Porifera rather than Ctenophora is the basal branch of the metazoan tree and that xenocoelomorphs are simplified relatives of echinoderms and chordates (Kapli \& Telford, 2020). The latter assumption leaves a clean Bilateria of the form (Deuterostomia (Ecdysozoa, Lophotrochozoa), which is ample for this discussion. I also accept tentatively (Fig. 12) the sibling relationship between Cnidaria and Ctenophora proposed by Zhao et al. (2019) based on their careful analysis of putative Cambrian stem members of the Ctenophora; this resurrects a monophyletic Coelenterata for the two phyla, a position adopted by Cavalier-Smith (2017) for entirely different reasons. The evolution of the metazoan stem lineage has been well reviewed by Cavalier-Smith (2017), Brunet \& King (2017) and Budd \& Jensen (2017); there is nothing to add except to note that Apoikozoa of Budd and Jensen (Choanoflagellata + Metazoa) yields to Choanozoa of Brunet and King. 


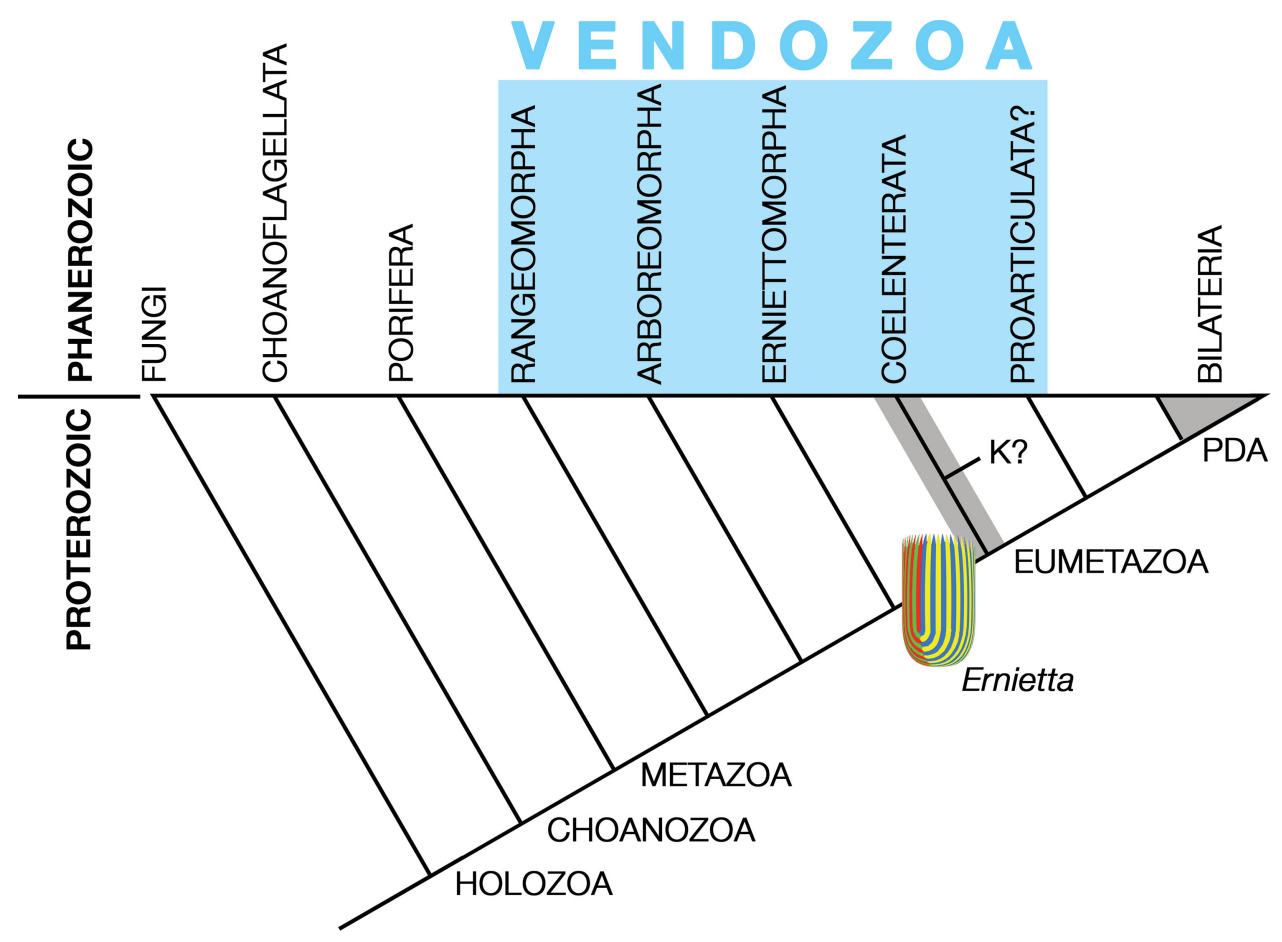

Fig. 12. Best-guess scenario for the relationships of Ediacaran organisms discussed in this review at the time of the Proterozoic-Phanerozoic boundary, when all of the groups shown in blue could have been easily accommodated in Seilacher's 'Vendozoa'. Ichthyosporea and Filasterea are omitted but lie between Fungi and Choanoflagellata; for the Metazoa, Porifera is treated as both basal and monophyletic, Placozoa (not shown) probably falls somewhere between sponges and coelenterates and Coelenterata consists of the sister phyla Cnidaria and Ctenophora, which may be either a clade (line) or a grade (shading). Ernietta is highlighted because it illustrates the degree of complexity that may have led to the early diverging eumetazoan phyla. The position of the Proarticulata is uncertain as it depends on whether or not its members had an alimentary canal (blind or through gut). If not, they should be lower in the diagram. K? stands for Kimberella, which as explained in the text, may have been a kind of foraging coelenterate; PDA is the protostome-deuterostome ancestor.

There is a continuing consensus that rangeomorphs and arboreomorphs are of cnidarian grade (Table 1), being constructed from inner and outer layers of cells with a collagenous structural layer of some sort in between. Cavalier-Smith (2017) suggested that this architecture could be pre-sponge, formed of layers of choanocytes on all unattached surfaces, but Dufour \& McIlroy $(2017,2018)$ thought this unlikely and instead proposed a pre-placozoan alternative with phagocytic cells on surfaces that are not exposed to ocean water. Similar ideas were foreshadowed by Pflug (1972a). Given the architectural complexity of rangeomorphs and arboreomorphs in comparison with sponges, including the Archaeocyatha, a pre-placozoan or pre-cnidarian grade seems more likely. As a starting point, rangeomorphs and arboreomorphs are placed somewhere between sponges and coelenterates on the metazoan tree (Fig. 12). Budd \& Jensen (2017) arrived at a similar conclusion but put rangeomorphs beneath the Porifera.

That is the easy part. But is it possible to use any of the other core Ediacarans to show how more complicated animals might have evolved? Glaessner and Wade apparently thought not: 'The Ediacara fauna in general appears too young to be the repository of links between many phyla. Coelenterates, annelids and arthropods were quite diversified by that time (Glaessner 1971)' (Wade, 1972a, p. 189). This was prior to the use of molecular clocks to estimate divergence times (e.g. Dohrmann \& Wörheide, 2017), but given the fact that stem ecdysozoans must date from at least the time of the first appearance datum (FAD) of Treptichnus pedum Seilacher, 1955 (Kesidis et al. 2019) and that the terminal Ediacaran worm Sabellidites cambriensis Yanishevsky, 1926 may be a crown group annelid (Moczydłowska et al. 2014; but see Georgieva et al. 2019), the same concern may still apply. On the other hand, Zhao et al. (2019) appear to have demonstrated considerable evolution of body form within the Cambrian in animals of coelenterate grade, so perhaps the game was not over by the later Ediacaran.

Two transformations in animal body plan that may be detectable in Ediacaran biology are the appearances of the cnidarian coelenteron and the bilaterian gut. These are traditionally attributed to larval innovations, as elegantly summarized in verse by Walter Garstang (1966). However, even though Haeckel's (1874) gastraea theory was derived from a sponge gastrula, the atrium (spongocoel) of sponges is not likely to be homologous with the coelenteron of cnidarians (Nielsen, 2008). Cavalier-Smith (2017) disagreed, arguing that the inside of a simple asconoid sponge is the forerunner of the cnidarian coelenteron. To some extent, this proposal resembles Pflug's petaloid cavity or 'centrarium' in that an enclosed piece of the open environment is co-opted for a body cavity. Cavalier-Smith then took the extraordinary step of transforming the cnidarian coelenteron into the bilaterian coelom by extending the pharynx into a gut that pierced the aboral body wall, creating an anus (Cavalier-Smith, 2017, fig. 3).

There may be another pathway to the cnidarian coelenteron that bypasses sponges completely. Imagine Ernietta as a stem cnidarian with the modules filled with mesenchyme, as envisaged by Dufour \& McIlroy (2017), and with seams between modules that will eventually become the mesenteries of an anthozoan polyp. The tapered growing ends of the modules may then have acquired nematocysts and became more muscular, allowing the animal to begin to collect higher quality food than previously possible. Furthermore, the bipolar symmetry of Ernietta may be superficial, given its close resemblance to Pteridinium and to a lesser extent Phyllozoon (Figs 3 , 
6; Gehling \& Runnegar, 2021). If so, cnidarians may have inherited 'bilaterian' body axes (L-R, A-P, D-V) from erniettomorphs.

Phylogenomic studies support a monophyletic Cnidaria comprising two principal clades, Anthozoa and Medusozoa $($ Hydrozoa + (Staurozoa, Scyphozoa, Cubozoa) $)$, and characterize the ancestral cnidarian as a solitary, non-symbiotic polyp that propagated by means of a planula larva (Pratlong et al. 2017; Kayal et al. 2018; Khalturin et al. 2019). Although (Khalturin et al. 2019) felt that the genetic and morphologic differences between anthozoan and medusozoan body forms were too great to support anything more complicated than a planula as their mutual last common ancestor, the presence of conserved minicollagen gene clusters, the products of which encode the principal structural protein of nematocytes in all major cnidarian clades, is an indication that the ancestor must have been large enough to need and use nematocysts. This argues for extreme divergence of current polyp architecture rather than a larval level latest common ancestor (LCA).

All anthozoans, including Palaeozoic rugose corals (Fig. 8b), are bilaterally symmetrical (Oliver, 1980). In the model anthozoan, the starlet sea anemone Nematostella Stephenson, 1935 (Frank \& Bleakney, 1976), the bilateral symmetry is expressed first in the early planula larva by an elongation of the oral opening and then by the disposition of the first eight mesenteries and the formation of the first four tentacles, two on either side of the symmetry plane (He et al. 2018). Subsequently, one end of the oral aperture becomes enlarged to form a ciliated groove (siphonoglyph), which serves as a landmark during further development. Thus, Nematostella and other anthozoans have a vectorial 'directive axis' that lies in the plane of symmetry (Fig. 8b). This axis expresses the products of some Hox and other positional genes during development and is therefore equated with the anterior-posterior axis of bilaterians (He et al. 2018; Nielsen et al. 2018; Technau \& Genikhovich, 2018). It follows that the oral-aboral axis of cnidarians is equivalent to the ventral-dorsal axis of bilaterians and perhaps to the lower and upper surfaces of Trichoplax, respectively (DuBuc et al. 2019). This 3D Cartesian coordinate system predates at least the coelenterates in metazoan evolution and may have been present in classic Ediacarans, including all of the taxa reviewed here. If so, how can this help us understand Ediacaran palaeobiology?

The two principal proposals for the derivation of the bilaterians from coelenterates are Haeckel's (1874) gastrea hypothesis and von Graff's paedomorphic planula hypothesis (Hejnol \& Martindale, 2009). Each requires larval adaptations that are expressed as new kinds of adults. In Haeckel's case, the archenteron of the larva, which resulted from gastrulation, becomes the gut of the adult. In protostomes, the oral aperture of the larva becomes the mouth, whereas in deuterostomes it becomes the anus. This problem of initial order was overcome by Sedgwick's (1884) amphistomy hypothesis, which derived the mouth and anus from opposite ends of an elongate blastopore; loss of one or other larval apertures then accounted for the protostome-deuterostome division (Nielsen, 2008; Hejnol \& Martindale, 2009). Nielsen et al. (2018) have advanced a strong case for early amphistomy, whereas Hejnol \& Martindale (2009) have equally firmly rejected both amphistomic gastrulation and Haeckel's gastrea. Nevertheless, amphistomic gastrulation helps solve the topological problem of deriving the A-P axis of a bilaterian from the directive axis, rather than the oral-aboral axis, of a coelenterate.

For the Ediacaran White Sea biota, these matters were investigated by Fedonkin $(1985 a, b)$ using the principles of promorphology (animal symmetry) expounded by Beklemishev (1969). However, in contrast to Sedgwick (1884), who suggested that the bilateral symmetry of an annelid is inherited from amphistomic development in the directive plane of an anemone, Fedonkin thought that the Ediacaran 'medusoids' were jellyfish of various symmetry classes (infinite, infinite and radial, uncertain, threefold, four-fold, etc.) that led directly to the more elongated but still somewhat radially arranged Proarticulata (Dickinsonia et al.). Thus, the glide symmetry of proarticulates represented an early attempt to transform radial elements into metameres, and the anterior-posterior axis of bilaterians was developed during this process. A similarly vague derivation was proposed by Malakhov (2016, p. 295), who speculated that 'it was the mobile mode of life [of Ediacaran proarticulates] that determined the development of antero-posterior polarity and bilaterial symmetry in the common ancestors of Cnidaria and triploblastic Bilateria.' This scenario is more clearly described by Arendt et al. (2015), who treated the 'gastric pouches' of Dickinsonia (Dzik, 2003, fig. 8; sediment-filled modules, as discussed in Section 5.c) and the compartments defined by the four pairs of mesenteries of a Nematostella 'edwardsia larva' (Daly, 2002), as homologous structures. They also suggested that the terminal addition of modules in Dickinsonia (Runnegar, 1982; Gold et al. 2015; Ivantsov et al. 2020) and mesenteries in anthozoans have a common developmental origin. The implication here is that the vagile habits of proarticulates are responsible for the directive axis in cnidarians, which is the opposite of what Sedgwick thought.

On the other hand, it may be that the quasi-bilateral symmetry of rangeomorphs, arboreomorphs, some erniettomorphs, and dickinsoniomorphs and their growth by terminal addition sensu lato formed the basis, first for coelenterate and then bilaterian symmetry, following Sedgwick's mechanism. In this case the holdfasts of fronds, the proximal ends of erniettomorphs and the 'head' regions of dickinsoniomorphs are anatomically 'anterior' in the bilaterian sense and their growing tips are 'posterior'. The coelenteron of cnidarians is derived from the 'centrarium' of an Ernietta-like animal, as previously explained, and evolutionary amphistomy (Nielsen et al. 2018), or perhaps evolutionary deuterostomy (Cavalier-Smith, 2017; Steinmetz et al. 2017; Nielsen et al. 2018; Steinmetz, 2019), then leads to the Bilateria. It is a wild speculation but one that may help focus thinking on the path ahead. The phylogenetic implications of this suggestion are illustrated in Figure 12. According to this theory, those forms with apparently bipolar symmetry, such as Fractofusus and Ernietta, are secondarily bipolar, having been able to relax the directive axis developmental constraints for lifestyle reasons. Glide symmetry represents a transitional step between the zig-zag axes of rangeomorphs, arboreomorphs, erniettomorphs and proarticulates and the sagittal plane symmetry of the Bilateria. Proarticulates may or may not have had a bilaterian gut, so their phylogenetic position remains uncertain (Fig. 12). Kimberella and other Ediacaran taxa not treated here are wildcards that are not easy to place, but there is little evidence to suggest that they were higher in the metazoan tree than coelenterate grade.

\section{Envoi}

As Breandán MacGabhann (2014) has aggressively noted, there is no such thing as the Ediacara biota; many other complex organisms were around at the same time. Nevertheless, to co-opt an ancient cliché, 'we recognize it when we see it'. It is in that spirit that we continue to explore the biology and phylogenetic meaning of these fascinating creatures. 


\section{Methods}

The Koch snowflakes (Fig. 8a) were plotted at https://online mathtools.com/generate-koch-snowflake. Aldus Super 3D 2.5 Macintosh OS 9.2 heritage software originally developed by Silicon Beach Software was used to construct the 3D models of Pteridinium and Ernietta shown in Figures 3, 9, 10 and 12. Illustrated specimens are in the following institutional collections: RAS PIN - Borissiak Palaeontological Institute, Russian Academy of Sciences, Moscow; SAM P - Palaeontology, South Australian Museum, Adelaide; UCLA - Earth, Planetary and Space Sciences, University of California, Los Angeles; or in private hands (Fig. 9a).

Acknowledgements. I thank Sören Jensen and his colleagues for the invitation to participate in IMECT 2019 and for hinting that a retrospective article of this kind might be an acceptable contribution to the meeting and the symposium volume. My knowledge of Ediacaran biotas has been gained through $\sim 40$ wonderful years working with Jim Gehling. Adolf (Dolf) Seilacher generously invited Jim and I to participate in his team's excavation of the Pteridinium bed on Aar Farm in 1993. Funding over the years has been provided by the Australian Research Grants Scheme, the U.S. National Science Foundation, the NASA Astrobiology Institute, the University of New England and UCLA. For generous discussion and advice, access to materials and vital assistance with field work I also thank Martin Glaessner, Mary Wade, Richard Jenkins, Neville Pledge, Christine Runnegar, Don Boyd, Chris Collins, Misha Fedonkin, Robert Horodyski, Gerard Germs, C. K. (Bob) Brain, Wilfried and Helmut Erni, Charles Hoffmann, Beverly Saylor, John Almond, Hans Pflug, Trevor Ford, Helen Boynton, Ben Bland, Mary Droser, Sören Jensen, Matt Saltzman, Lars Holmer, Kevin Peterson, Roger Summons and David Gold. Graham Budd and an anonymous reviewer kindly pointed out some serious problems with the submitted manuscript.

\section{References}

Anderson MM and Misra SB (1968) Fossils found in the Pre-Cambrian Conception Group of south-eastern Newfoundland. Nature 220, 680-1.

Antcliffe JB and Brasier MD (2006) Charnia at 50: developmental models for Ediacaran fronds. Palaeontology 51, 11-26.

Arendt D, Benito-Gutierrez E, Brunet T and Marlow H (2015) Gastric pouches and the mucociliary sole: setting the stage for nervous system evolution. Philosophical Transactions of the Royal Society B: Biological Sciences 370, 20150286. doi: 10.1098/rstb.2015.0286.

Bassler RS (1941) A supposed jellyfish from the Pre-Cambrian of the Grand Canyon. Proceedings of the United States National Museum 89, 519-22.

Beklemishev VN (1969) Principles of Comparative Anatomy of Invertebrates. Edinburgh: Oliver and Boyd.

Bengtson S (1986) The problem of the Problematica. In Problematical Fossil Taxa (eds A Hoffman and MH Nitecki), pp. 3-11. New York: Oxford University Press.

Bengtson S, Matthews SC and Missarzhevsky VV (1986) The Cambrian netlike fossil Microdictyon. In Problematical Fossil Taxa (eds A Hoffman and MH Nitecki), pp. 97-115. New York: Oxford University Press.

Billings E (1872) Fossils in Huronian rocks. Canadian Naturalist and Quarterly Journal of Science 6, 478.

Bobrovskiy I, Hope JM, Golubkova E and Brocks JJ (2020) Food sources for the Ediacara biota communities. Nature Communications 11, 1261. doi: 10.1038/s41467-020-15063-9.

Bobrovskiy I, Hope JM, Ivantsov A, Nettersheim BJ, Hallmann C and Brocks JJ (2018) Ancient steroids establish the Ediacaran fossil Dickinsonia as one of the earliest animals. Science 361, 1246-9.

Bobrovskiy I, Krasnova A, Ivantsov A, Luzhnaya E and Brocks JJ (2019) Simple sediment rheology explains the Ediacara biota preservation. Nature Ecology \& Evolution 3, 582-9.

Bond C and Harris AK (1988) Locomotion of sponges and its physical mechanism. Journal of Experimental Zoology 246, 271-84.

Bonner JT and Lamont DS (2005) Behavior of cellular slime molds in the soil. Mycologia 97, 178-84.
Bradshaw SA, O'Hara SCM, Cornert EDS and Eglinton G (1990) Changes in lipids during simulated herbivorous feeding by the marine crustacean Neomysis integer. Journal of the Marine Biological Association of the United Kingdom 70, 225-43.

Brasier MD, Antcliffe JB and Liu AG (2012) The architecture of Ediacaran fronds. Palaeontology 55, 1105-24.

Bright M, Espada-Hinojosa S, Volland J-M, Drexel J, Kesting J, Kolar I, Morchner D, Nussbaumer A, Ott J, Scharhauser F, Schuster L, Zambalos HC and Nemeschkal HL (2019) Thiotrophic bacterial symbiont induces polyphenism in giant ciliate host Zoothamnium niveum. Scientific Reports 9, 15081. doi: 10.1038/s41598-019-51511-3.

Bright M and Sorgo A (2003) Ultrastructural reinvestigation of the trophosome in adults of Riftia pachyptila (Annelida, Siboglinidae). Invertebrate Biology 122, 347-68.

Brocks JJ, Jarrett AJM, Sirantoine E, Hallmann C, Hoshino Y and Liyanage T (2017) The rise of algae in Cryogenian oceans and the emergence of animals. Nature 548, 578-81.

Brunet $\mathbf{T}$ and King $\mathbf{N}$ (2017) The origin of animal multicellularity and cell differentiation. Developmental Cell 43, 124-40.

Brunet T, Larson BT, Linden TA, Vermeij MJA, McDonald K and King N (2019) Light-regulated collective contractility in a multicellular choanoflagellate. Science 366, 326-34.

Budd GE and Jensen S (2017) The origin of the animals and a 'Savannah' hypothesis for early bilaterian evolution. Biological Reviews 92, 446-73.

Burki F, Roger AJ, Brown MW and Simpson AGB (2020) The new tree of eukaryotes. Trends in Ecology \& Evolution 35, 43-55.

Buss LW and Seilacher A (1994) The Phylum Vendobionta: a sister group of the Eumetazoa? Paleobiology 20, 1-4.

Butterfield NJ (2020) Constructional and functional anatomy of Ediacaran rangeomorphs. Geological Magazine, published online 3 August 2020. doi: $10.1017 /$ S0016756820000734

Caster KE (1945) A new jellyfish (Kirklandia texana Caster) from the Lower Cretaceous of Texas. Palaeontographica Americana 3, 1-52.

Caster KE (1957) Annotated bibliography of marine paleoecology: Problematica. In Treatise on Marine Ecology and Paleoecology (ed. HS Ladd), 1025-32. Geological Society of America, Memoirs vol. 67, Part II.

Cavalier-Smith T (2017) Origin of animal multicellularity: precursors, causes, consequences-the choanoflagellate/sponge transition, neurogenesis and the Cambrian explosion. Philosophical Transactions of the Royal Society B: Biological Sciences 372, 20150476. doi: 10.1098/rstb.2015.0476.

Chipman AD (2010) Parallel evolution of segmentation by co-option of ancestral gene regulatory networks. Bioessays 32, 60-70.

Chipman AD and Edgecombe GD (2019) Developing an integrated understanding of the evolution of arthropod segmentation using fossils and evo-devo. Proceedings of the Royal Society B: Biological Sciences 286, 20191881. doi: 10.1098/rspb.2019.1881.

Cooper BJ and Branagan DF (2015) The 25th International Geological Congress, Sydney, Australia (1976). Episodes 38, 1-10.

Crimes TP (1970) Trilobite tracks and other trace fossils from the Upper Cambrian of North Wales. Geological Journal 7, 47-68.

Crimes TP and Fedonkin MA (1996) Biotic changes in platform communities across the Precambrian-Phanerozoic boundary. Revista Italiana di Paleontologia e Stratigrafia 102, 317-32.

Daly M (2002) A systematic revision of Edwardsiidae (Cnidaria, Anthozoa) Invertebrate Biology 121, 212-25.

Dececchi TA, Narbonne GM, Greentree C and Laflamme M (2017) Relating Ediacaran fronds. Paleobiology 43, 171-80.

Deline B, Greenwood JM, Clark JW, Puttick MN, Peterson KJ and Donoghue PCJ (2018) Evolution of metazoan morphological disparity. Proceedings of the National Academy of Sciences 115, E8909-E8918. doi: 10.1073/pnas. 1810575115.

Dewel RA, Dewel WC and McKinney FK (2001) Diversification of the Metazoa: Ediacarans, colonies and the origin of eumetazoan complexity by nested modularity. Historical Biology 15, 193-218.

Dohrmann M and Wörheide G (2017) Dating early animal evolution using phylogenomic data. Scientific Reports 7, 3599. doi: 10.1038/s41598017-03791-w. 
Droser ML, Gehling JG and Jensen SR (2006) Assemblage palaeoecology of the Ediacara biota: the unabridged edition? Palaeogeography, Palaeoclimatology Palaeoecology 232, 131-47.

Droser ML, Gehling JG, Tarhan LG, Evans SD, Hall CMS, Hughes IV, Hughes EB, Dzaugis ME, Dzaugis MP, Dzaugis PW and Rice D (2019) Piecing together the puzzle of the Ediacara Biota: excavation and reconstruction at the Ediacara National Heritage site Nilpena (South Australia). Palaeogeography, Palaeoclimatology, Palaeoecology 513, 132-45.

Droser ML, Tarhan LG and Gehling JG (2017) The rise of animals in a changing environment: global ecological innovation in the late Ediacaran. Annual Review of Earth and Planetary Sciences 45, 593-617.

DuBuc TQ, Ryan JF and Martindale MQ (2019) 'Dorsal-ventral' genes are part of an ancient axial patterning system: evidence from Trichoplax adhaerens (Placozoa). Molecular Biology and Evolution 36, 966-73.

Dufour SC and McIlroy D (2017) Ediacaran pre-placozoan diploblasts in the Avalonian biota: the role of chemosynthesis in the evolution of early animal life. In Earth System Evolution and Early Life: A Celebration of the Work of Martin Brasier (eds AT Brasier, D McIlroy and N McLoughlin), pp. 211-19. Geological Society of London, Special Publication no. 448.

Dufour SC and McIlroy D (2018) An Ediacaran pre-placozoan alternative to the pre-sponge route towards the Cambrian explosion of animal life: a comment on Cavalier-Smith 2017. Philosophical Transactions of the Royal Society B: Biological Sciences 373, 20170148. doi: 10.1098/rstb.2017.0148.

Dunn FS and Liu AG (2019) Viewing the Ediacaran biota as a failed experiment is unhelpful. Nature Ecology \& Evolution 3, 512-14.

Dunn FS, Liu AG and Donoghue PCJ (2018) Ediacaran developmental biology. Biological Reviews 93, 914-32.

Dunn FS, Liu AG and Gehling JG (2019) Anatomical and ontogenetic reassessment of the Ediacaran frond Arborea arborea and its placement within tota group Eumetazoa. Palaeontology 62, 851-65.

Dzik J (1999) Organic membranous skeleton of the Precambrian metazoans from Namibia. Geology 27, 519-22.

Dzik J (2003) Anatomical information content in the Ediacaran fossils and their possible zoological affinities. Integrative and Comparative Biology $\mathbf{4 3}$, 114-26.

Dzik J and Ivantsov AY (2002) Internal anatomy of a new Precambrian dickinsoniid dipleurozoan from northern Russia. Neues Jahrbuch für Geologie und Paläontologie Monatshefte 2002, 385-96.

Elliott DA, Trusler PW, Narbonne GM, Vickers-Rich P, Morton N, Hall M, Hoffmann KH and Schneider GIC (2016) Ernietta from the late Ediacaran Nama Group, Namibia. Journal of Paleontology 90, 1017-26.

Erwin DH (2020) The origin of animal body plans: a view from fossil evidence and the regulatory genome. Development 147, dev182899. doi: 10.1242/dev. 182899.

Erwin DH, Laflamme M, Tweedt SM, Sperling EA, Pisani D and Peterson KJ (2011) The Cambrian conundrum: early divergence and later ecological success in the early history of animals. Science 334, 1091-7.

Evans SD, Droser ML and Erwin DH (2021) Developmental processes in Ediacara macrofossils. Proceedings of the Royal Society B: Biological Sciences 288, 20203055. doi: 10.1098/rspb.2020.3055.

Evans SD, Droser ML and Gehling JG (2017) Highly regulated growth and development of the Ediacara macrofossil Dickinsonia costata. PLoS ONE 12, e0176874. doi: 10.1371/journal.pone.0176874.

Evans SD, Gehling JG and Droser ML (2019) Slime travelers: early evidence of animal mobility and feeding in an organic mat world. Geobiology 17, 490-509.

Fedonkin MA (1983) Non-skeletal fauna of Podolia (Dniestr River Valley). In The Vendian of Ukraine (eds VA Velikanov, MA Aseeva and MA Fedonkin), pp. 128-39. Kiev: Naukova Dumka (in Russian).

Fedonkin MA (1985a) Precambrian metazoans: the problem of preservation, systematics and evolution. Philosophical Transactions of the Royal Society B: Biological Sciences 311, 27-45.

Fedonkin MA (1985b) Systematic description of Vendian Metazoa. In The Vendian System, Vol. 1, Paleontology (eds BS Sokolov and AB Iwanowski), pp. 70-106. Moscow: Nauka (in Russian).

Fedonkin MA (1987) Non-skeletal fauna of the Vendian and its place in the evolution of metazoans. Transactions of the Paleontological Institute, Academy of Sciences U.S.S.R. 226, 1-174 (in Russian).
Fedonkin MA (1998) Metameric features in the Vendian metazoans. Italian Journal of Zoology 65, 11-17.

Fedonkin MA (2002) Andiva ivantsovi gen et sp. n. and related carapacebearing Ediacaran fossils from the Vendian of the Winter Coast, White Sea, Russia. Italian Journal of Zoology 69, 175-281.

Fedonkin MA, Simonetta A and Ivantsov AY (2007) New data on Kimberella the Vendian mollusc-like organism (White Sea Region, Russia): palaeoecological and evolutionary implications. In The Rise and Fall of the Ediacaran Biota (eds P Vickers-Rich and P Komarower), pp. 157-79. Geological Society of London, Special Publication no. 286.

Fedonkin MA and Waggoner B (1997) The Late Precambrian fossil Kimberella is a mollusc-like bilaterian organism. Nature 388, 868-71.

Ford TD (1958) Pre-Cambrian fossils from Charnwood Forest. Proceedings of the Yorkshire Geological Society 31, 211-17.

Ford TD (1980) The Ediacaran fossils of Charnwood Forest, Leicestershire. Proceedings of the Geologists' Association 91, 81-3.

Frank P and Bleakney JS (1976) Histology and sexual reproduction of the anemone Nematostella vectensis Stephenson 1935. Journal of Natural History 10, 441-9.

Fürsich FT and Kennedy WJ (1975) Kirklandia texana Caster - Cretaceous hydrozoan medusoid of trace fossil chimaera? Palaeontology 18, 665-79.

Garstang W (1966) Larval Forms with Other Zoological Verses. Oxford: Basil Blackwell.

Gehling JG (1991) The case for Ediacaran fossil roots to the metazoan tree. Geological Society of India Memoir 20, 181-224

Gehling JG (1999) Microbial mats in terminal Proterozoic siliciclastics: Ediacaran death masks. Palaios 14, 40-57.

Gehling JG (2000) Environmental interpretation and a sequence stratigraphic framework for the terminal Proterozoic Ediacara Member within the Rawnsley Quartzite, South Australia. Precambrian Research 100, 65-95.

Gehling JG (2005) Field Guide to the Ediacaran-Cambrian of the Flinders Ranges, South Australia (IGCP493). Adelaide: South Australian Museum.

Gehling JG and Droser ML (2013) How well do fossil assemblages of the Ediacara Biota tell time? Geology 41, 447-50.

Gehling JG, Droser ML, Jensen SR and Runnegar B (2005) Ediacara organisms: relating form to function. In Evolving Form and Function: Fossils and Development (ed. DEG Briggs), pp. 43-66. New Haven, Connecticut: Peabody Museum of Natural History, Yale University.

Gehling JG and Narbonne GM (2007) Spindle-shaped Ediacara fossils from the Mistaken Point assemblage, Avalon Zone, Newfoundland. Canadian Journal of Earth Sciences 44, 367-87.

Gehling JG, Narbonne GM and Anderson MM (2000) The first named Ediacaran body fossil, Aspidella terranovica. Palaeontology 43, 427-56.

Gehling JG and Runnegar B (2021) Phyllozoon and Aulozoon-key components of a novel Ediacaran death assemblage in Bathtub Gorge, Heysen Range, South Australia. Geological Magazine. doi: 10.1017/S0016756821 000509.

Gehling JG, Runnegar BN and Droser ML (2014) Scratch traces of large Ediacara bilaterian animals. Journal of Paleontology 88, 284-98.

Georgieva MN, Little Crispin TS, Watson JS, Sephton MA, Ball AD and Glover AG (2019) Identification of fossil worm tubes from Phanerozoic hydrothermal vents and cold seeps. Journal of Systematic Palaeontology 17, 287-329

Germs GJB (1973) A reinterpretation of Rangea schneiderhoehni and the discovery of a related new fossil from the Nama Group, South West Africa. Lethaia 6, 1-9.

Ghisalberti M, Gold DA, Laflamme M, Clapham ME, Narbonne GM, Summons RE, Johnston DT and Jacobs DK (2014) Canopy flow analysis reveals the advantage of size in the oldest communities of multicellular eukaryotes. Current Biology 24, 305-9.

Gibson BM, Furbish DJ, Rahman IA, Schmeeckle MW, Laflamme M and Darroch SF (2021) Ancient life and moving fluids. Biological Reviews 96, 129-52.

Gibson BM, Rahman IA, Maloney KM, Racicot RA, Mocke H, Laflamme M and Darroch SAF (2019) Gregarious suspension feeding in a modular Ediacaran organism. Science Advances 5, eaaw0260. doi: 10.1126/sciadv. aaw0260. 
Glaessner MF (1958) New fossils from the base of the Cambrian in South Australia. Transactions of the Royal Society of South Australia 81, 185-8.

Glaessner MF (1959a) The oldest fossil faunas of South Australia. Geologische Rundschau 47, 522-31.

Glaessner MF (1959b) Precambrian Coelenterata from Australia, Africa and England. Nature 183, 1472-3.

Glaessner MF (1961) Pre-Cambrian animals. Scientific American 204, $72-8$

Glaessner MF (1962) Pre-Cambrian fossils. Biological Reviews 37, 467-94.

Glaessner MF (1963) Zur Kenntnis der Nama-Fossilien Südwest-Afrikas. Annalen des Naturhistorischen Museums in Wien 66, 113-20.

Glaessner MF (1971) Geographic distribution and time range of the Ediacara Precambrian fauna. Geological Society of America Bulletin 82, 509-14.

Glaessner MF (1984) The Dawn of Animal Life. A Biohistorical Study. Cambridge: Cambridge University Press.

Glaessner MF and Daily B (1959) The geology and late Precambrian fauna of the Ediacara fossil reserve. Records of the South Australian Museum 13, 369-401.

Glaessner MF and Wade M (1966) The late Precambrian fossils from Ediacara, South Australia. Palaeontology 9, 97-103.

Glaessner MF and Wade M (1971) The genus Conomedusites Glaessner and Wade and the diversification of the Cnidaria. Paläontolische Zeitschrift 45 , 7-17.

Gold DA, Runnegar B, Gehling JG and Jacobs DK (2015) Ancestral state reconstruction of ontogeny supports a bilaterian affinity for Dickinsonia. Evolution \& Development 17, 315-24.

Gould SJ (1984) The Ediacaran experiment. Natural History, New York 93 14-23.

Grazhdankin D and Seilacher A (2002) Underground Vendobionta from Namibia. Palaeontology 45, 57-78.

Gürich G (1930) Die bislang ältesten Spuren von Organismen in Südafrika. 15th International Geological Congress, South Africa, Comptes Rendus 2, 670-81.

Gürich G (1933) Die Kuibis-Fossilien der Nama-Formation von Südwestafrika. Paläontolische Zeitschrift 15, 137-54.

Haeckel E (1874) Die Gastraea-Theorie, die phylogenetische Classification des Thierreichs und die Homologie der Keimblätter. Jenaische Zeitschrift für Naturwissenschaft 8, 1-55.

Hall JG, Smith EF, Tamura N, Fakra SC and Bosak T (2020) Preservation of erniettomorph fossils in clay-rich siliciclastic deposits from the Ediacaran Wood Canyon Formation, Nevada. Interface Focus 10, 20200012. doi: 10.1098/rsfs.2020.0012.

Harrington HJ and Moore RC (1955) Fossil jellyfish from Kansas Pennsylvanian rocks and elsewhere. State Geological Survey of Kansas Bulletin 114, 153-64.

He S, Del Viso F, Chen C-Y, Ikmi A, Kroesen AE and Gibson MC (2018) An axial Hox code controls tissue segmentation and body patterning in Nematostella vectensis. Science 361, 1377-80.

Hejnol A and Martindale MQ (2009) The mouth, the anus, and the blastopore-open questions about questionable openings. In Animal Evolution: Genomes, Fossils and Trees (eds MJ Telford and DTJ Littlewood), pp. 33-40. Oxford: Oxford University Press.

Hill D (1964) The phylum Archaeocyatha. Biological Reviews 39, 232-58.

Hodgin EB, Nelson LL, Wall CJ, Barrón-Díaz AJ, Webb LC, Schmitz MD, Fike DA, Hagadorn JW and Smith EF (2020) A link between rift-related volcanism and end-Ediacaran extinction? Integrated chemostratigraphy, biostratigraphy, and $\mathrm{U}-\mathrm{Pb}$ geochronology from Sonora, Mexico. Geology 49, 115-19.

Hoekzema RS, Brasier MD, Dunn FS and Liu AG (2017) Quantitative study of developmental biology confirms Dickinsonia as a metazoan. Proceedings of the Royal Society B: Biological Sciences 284, 20171348. doi: 10.1098/rspb. 2017.1348.

Hofmann HJ (1988) An alternative interpretation of the Ediacaran (Precambrian) chondrophore Chondroplon Wade. Alcheringa: An Australasian Journal of Palaeontology 12, 315-18.

Hofmann HJ, O'Brien SJ and King AF (2008) Ediacaran biota on Bonavista Peninsula, Newfoundland, Canada. Journal of Paleontology 82, 1-36.

Holmes A (1959) A revised geological time-scale. Transactions of the Edinburgh Geological Society 17, 183-216.
Hoyal Cuthill JF and Han J (2018) Cambrian petalonamid Stromatoveris phylogenetically links Ediacaran biota to later animals. Palaeontology 61 , 813-23.

Ivantsov AY (1999) A new dickinsonid from the upper Vendian of the White Sea Winter Coast (Russia, Arkhangelsk Region). Paleontological Journal 33 211-21.

Ivantsov AY (2004) New Proarticulata from the Vendian of the Arkhangel'sk Region. Paleontological Journal 38, 247-53.

Ivantsov AY (2007) Small Vendian transversely articulated fossils. Paleontological Journal 41, 113-22.

Ivantsov AY (2009) New reconstruction of Kimberella, problematic Vendian metazoan. Paleontological Journal 434, 601-11.

Ivantsov AY (2011) Feeding traces of Proarticulata-the Vendian Metazoa. Paleontological Journal 43, 237-48.

Ivantsov AY (2013) Trace fossils of Precambrian Metazoa 'Vendobionta' and 'Mollusks'. Stratigraphy and Geological Correlation 21, 252-64.

Ivantsov AY (2016) Reconstruction of Charniodiscus yorgensis (macrobiota from the Vendian of the White Sea). Paleontological Journal 50, 1-12.

Ivantsov AY (2017) The most probable Eumetazoa among late Precambrian macrofossils. Invertebrate Zoology 14, 127-33.

Ivantsov AY, Fedonkin MA, Nagovitsyn AL and Zakrevskaya MA (2019a) Cephalonega, a new generic name, and the system of Vendian Proarticulata. Paleontological Journal 53, 447-54.

Ivantsov AY and Malakhovskaya YA (2002) Giant traces of Vendian animals. Doklady Earth Sciences 385A, 618-22.

Ivantsov AY, Nagovitsyn AL and Zakrevskaya MA (2019b) Traces of locomotion of Ediacaran macroorganisms. Geosciences 9, 395. doi: 10.3390/ geosciences 9090395.

Ivantsov AY, Narbonne GM, Trusler PW, Greentree C and Vickers-Rich P (2016) Elucidating Ernietta: new insights from exceptional specimens in the Ediacaran of Namibia. Lethaia 49, 540-54.

Ivantsov AY and Zakrevskaya MA (2021a) Dickinsonia: mobile and adhered. Geological Magazine, published online 12 April 2021. doi: 10.1017/ S0016756821000194.

Ivantsov AY and Zakrevskaya MA (2021b) Trilobozoa, Precambrian triradial organisms. Paleontological Journal 55, 13-27.

Ivantsov AY and Zakrevskaya MA (2021c) Symmetry of Vendobionta (Late Precambrian Metazoa). Paleontological Journal 55, 3-12.

Ivantsov AY, Zakrevskaya MA and Nagovitsyn AL (2019c) Morphology of integuments of the Precambrian animals, Proarticulata. Invertebrate Zoology 16, 19-26.

Ivantsov AY, Zakrevskaya MA, Nagovitsyn AL, Krasnova A, Bobrovskiy I and Luzhnaya (Serezhnikova) E (2020) Intravital damage to the body of Dickinsonia (Metazoa of the late Ediacaran). Journal of Paleontology $\mathbf{9 4}$ 1919-33.

Jenkins RJF (1984) Interpreting the oldest fossil cnidarians. Palaeontographica Americana 54, 95-104.

Jenkins RJF (1985) The enigmatic Ediacaran (late Precambrian) genus Rangea and related forms. Paleobiology 11, 336-55.

Jenkins RJF (1989) The supposed terminal Precambrian extinction event in relation to the Cnidaria. Memoirs of the Association of Australasian Palaeontologists 8, 307-17.

Jenkins RJF (1992) Functional and ecological aspects of Ediacaran assemblages. In Origin and Early Evolution of the Metazoa (eds JH Lipps and PW Signor), pp. 131-76. New York and London: Plenum Press.

Jenkins RJF (1995) The problems and potential of using animal fossils and trace fossils in terminal Proterozoic biostratigraphy. Precambrian Research 73, 51-69.

Jenkins RJF and Gehling JG (1978) A review of the frond-like fossils of the Ediacara assemblage. Records of the South Australian Museum 17, 347-59.

Jenkins RJF, Plummer PS and Moriarty KC (1981) Late Precambrian pseudofossils from the Flinders Ranges, South Australia. Transactions of the Royal Society of South Australia 105, 67-83.

Jones ML (1981) Riftia pachyptila Jones: observations on the vestimentiferan worm from the Galápagos Rift. Science 213, 333-6.

Kapli P and Telford MJ (2020) Topology-dependent asymmetry in systematic errors affects phylogenetic placement of Ctenophora and Xenacoelomorpha. Science Advances 6, eabc5162. doi: 10.1126/sciadv.abc5162. 
Kayal E, Bentlage B, Sabrina Pankey M, Ohdera AH, Medina $M$ Plachetzki DC, Collins AG and Ryan JF (2018) Phylogenomics provides a robust topology of the major cnidarian lineages and insights on the origins of key organismal traits. BMC Evolutionary Biology 18, 68. doi: 10.1186/ s12862-018-1142-0.

Keller BM (1969) Impression from unknown animal from the Valdaian series of Russian Platform. In The Tommotian Stage and the Lower Cambrian Boundary Problem (ed. ME Raaben), pp. 175-6. Trudy AN SSSR 206 Moscow: Nauka (in Russian).

Keller BM and Fedonkin MA (1976) New organic fossil finds in the Precambrian Valday Series along the Syuzma River. Izvestiya Akademi Nauk SSSR, Seriya Geologicheskaya 3, 38-44 (in Russian).

Kesidis G, Slater BJ, Jensen S and Budd GE (2019) Caught in the act: priapulid burrowers in early Cambrian substrates. Proceedings of the Royal Society $B$ Biological Sciences 286, 20182505. doi: 10.1098/rspb.2018.2505.

Khalturin K, Shinzato C, Khalturina M, Hamada M, Fujie M, Koyanagi R, Kanda M, Goto H, Anton-Erxleben F, Toyokawa M, Toshino S and Satoh N (2019) Medusozoan genomes inform the evolution of the jellyfish body plan. Nature Ecology \& Evolution 3, 811-22.

Kozlowski R (1947) Les affinités des graptolithes. Biological Reviews 22, 93-108.

Kriaa A, Bourgin M, Mkaouar H, Jablaoui A, Akermi N, Soussou S, Maguin E and Rhimi M (2019) Microbial reduction of cholesterol to coprostanol: an old concept and new insights. Catalysts 9, 167.

Kruse PD (1990) Are archaeocyaths sponges, or are sponges archaeocyaths? In The Evolution of a Late Precambrian-Early Palaeozoic Rift Complex The Adelaide Geosyncline (eds JB Jago and RS Moore), pp. 310-23. Adelaide: Geological Society of Australia.

Laflamme M, Flude LI and Narbonne GM (2012) Ecological tiering and the evolution of a stem: the oldest stemmed frond from the Ediacaran of Newfoundland, Canada. Journal of Paleontology 86, 193-200.

Laflamme M, Gehling JG and Droser ML (2018) Deconstructing an Ediacaran frond: three-dimensional preservation of Arborea from Ediacara, South Australia. Journal of Paleontology 92, 323-35.

Laflamme M and Narbonne GM (2008) Ediacaran fronds. Palaeogeography, Palaeoclimatology, Palaeoecology 258, 162-79.

Laflamme M, Narbonne GM and Anderson MM (2004) Morphometric analysis of the Ediacaran frond Charniodiscus from the Mistaken Point Formation, Newfoundland. Journal of Paleontology 78, 827-37.

Laflamme M, Narbonne GM, Greentree C and Anderson MM (2007) Morphology and taphonomy of an Ediacaran frond: Charnia from the Avalon Peninsula of Newfoundland. In The Rise and Fall of the Ediacaran Biota (eds P Vickers-Rich and P Komarower), pp. 237-57. Geological Society of London, Special Publication no. 286.

Laflamme M, Xiao S and Kowalewski M (2009) Osmotrophy in modular Ediacara organisms. Proceedings of the National Academy of Sciences 106, 14438-43.

Landing E, Antcliffe JB, Geyer G, Kouchinsky A, Bowser SS and Andrease A (2018) Early evolution of colonial animals (Ediacaran evolutionary radiation-Cambrian evolutionary radiation-Great Ordovician Biodiversification interval). Earth-Science Reviews 178, 105-35.

Li C, Shi W, Cheng M, Jin C and Algeo TJ (2020) The redox structure of Ediacaran and early Cambrian oceans and its controls. Science Bulletin $\mathbf{6 5}$, 2141-9.

Linnemann U, Ovtcharova M, Schaltegger U, Gärtner A, Hautmann M, Geyer G, Vickers-Rich P, Rich T, Plessen B, Hofmann M, Zieger J, Krause R, Kriesfeld L and Smith J (2019) New high-resolution age data from the Ediacaran-Cambrian boundary indicate rapid, ecologically driven onset of the Cambrian explosion. Terra Nova 31, 49-58.

Liu AG, McMahon S, Matthews JJ, Still JW and Brasier AT (2019) Petrological evidence supports the death mask model for the preservation of Ediacaran soft-bodied organisms in South Australia. Geology 47, 215-18.

Luicking R and Nelsen MP (2018) Ediacarans, protolichens, and lichen-derived Penicillium: a critical reassessment of the evolution of lichenization in Fungi. In Transformative Paleobotany (eds M Krings, CJ Harper, NR Cúneo and GW Rothwell), pp. 551-90. London: Academic Press.

MacGabhann BA (2014) There is no such thing as the 'Ediacara Biota'. Geoscience Frontiers 5, 53-62.
Malakhov VV (2016) Symmetry and the tentacular apparatus in Cnidaria Russian Journal of Marine Biology 42, 287-98.

Manton SM (1967) The polychaete Spinther and the origin of the Arthropoda Journal of Natural History 1, 1-22.

Martí Mus M, Jeppsson L and Malinky JM (2014) A complete reconstruction of the hyolithid skeleton. Journal of Paleontology 88, 160-70.

Martin GG (1978) Ciliary gliding in lower invertebrates. Zoomorphologie 91 249-61.

Matthews JJ, Liu AG, Yang C, McIlroy D, Levell B and Condon DJ (2021) A chronostratigraphic framework for the rise of the Ediacaran macrobiota: new constraints from Mistaken Point Ecological Reserve, Newfoundland. Geological Society of America Bulletin 133, 612-24.

McCartney M (2021) The area, centroid and volume of revolution of the Koch curve. International Journal of Mathematical Education in Science and Technology 52, 782-6. doi: 10.1080/0020739X.2020.1747649.

McIlroy D, Brasier MD and Lang AS (2009) Smothering of microbial mats by macrobiota: implications for the Ediacara biota. Journal of the Geological Society, London 166, 1117-21.

McIlroy D, Dufour SC, Taylor R and Nicholls R (2021) The role of symbiosis in the first colonization of the seafloor by macrobiota: insights from the oldest Ediacaran biota (Newfoundland, Canada). Biosystems 205, 104413. doi: 10.1016/j.biosystems.2021.104413.

McIlroy D, Hawco J, McKean C, Nicholls R, Pasinetti G and Taylor R (2020) Palaeobiology of the reclining rangeomorph Beothukis from the Ediacaran Mistaken Point Formation of southeastern Newfoundland. Geological Magazine, published online 24 September 2020. doi: 10.1017/S001675682 0000941.

McKay CP (2004) What is life-and how do we search for it in other worlds? PLoS Biol 2, e302. doi: 10.1371/journal.pbio.0020302.

McMahon WJ, Liu AG, Tindal BH and Kleinhans MG (2021) Ediacaran life close to land: coastal and shoreface habitats of the Ediacaran macrobiota, the Central Flinders Ranges, South Australia. Journal of Sedimentary Research 90, 1463-99.

McMenamin MS (1986) The Garden of Ediacara. Palaios 1, 178-82.

Melendez I, Grice K and Schwark L (2013) Exceptional preservation of Palaeozoic steroids in a diagenetic continuum. Scientific Reports 3, 2768. doi: $10.1038 /$ srep02768.

Meyer M, Elliott D, Schiffbauer JD, Hall M, Hoffman KH, Schneider G, Vickers-Rich P and Xiao S (2014a) Taphonomy of the Ediacaran fossil Pteridinium simplex preserved three-dimensionally in mass flow deposits, Nama Group, Namibia. Journal of Paleontology 88, 240-52.

Meyer M, Elliott D, Wood AD, Polys NF, Colbert M, Maisano JA, Vickers-Rich P, Hall M, Hoffman KH, Schneider G and Xiao S (2014b) Three-dimensional microCT analysis of the Ediacara fossil Pteridinium simplex sheds new light on its ecology and phylogenetic affinity. Precambrian Research 249, 79-87.

Minicucci JM (2017) Who was the first person known to have discovered fossils of the Precambrian (Ediacaran) organism Aspidella terranovica? Geoscience Canada 44, 55-61.

Mitchell CE, Melchin MJ, Cameron CB and Maletz J (2013) Phylogenetic analysis reveals that Rhabdopleura is an extant graptolite. Lethaia $\mathbf{4 6}$ $34-56$.

Moczydłowska M, Westall F and Foucher F (2014) Microstructure and biogeochemistry of the organically preserved Ediacaran metazoan Sabellidites. Journal of Paleontology 88, 224-39.

Narbonne GM (1998) The Ediacara Biota: a terminal Neoproterozoic experiment in the evolution of life. GSA Today 8, 1-6.

Narbonne GM (2004a) The Ediacara biota: Neoproterozoic origin of animals and their ecosystems. Annual Review of Earth and Planetary Sciences 33 421-42.

Narbonne GM (2004b) Modular construction of early Ediacaran complex life forms. Science 305, 1141-4

Narbonne GM, Laflamme M, Greentree C and Trusler P (2009) Reconstructing a lost world: Ediacaran rangeomorphs from Spaniard's Bay, Newfoundland. Journal of Paleontology 83, 503-23.

Narbonne GM, Saylor BZ and Grotzinger JP (1997) The youngest Ediacaran fossils from southern Africa. Journal of Paleontology 71, 953-67. 
Nicholson HA (1878) VI.-On the minute structure of the corals of the genera Heliophyllum and Crepidophyllum. Annals and Magazine of Natural History 1, 44-54.

Nielsen C (2008) Six major steps in animal evolution: are we derived sponge larvae? Evolution \& Development 10, 241-57.

Nielsen C, Brunet T and Arendt D (2018) Evolution of the bilaterian mouth and anus. Nature Ecology \& Evolution 2, 1358-76.

Oliver WA (1980) The relationship of the scleractinian corals to the rugose corals. Paleobiology 6, 146-60.

Oliver WA and Coates AG (1987) Phylum Cnidaria. In Fossil Invertebrates (eds RS Boardman, RS Cheetham and AH Rowell), pp. 140-93. Oxford: Blackwell Scientific Publications.

Owen G (1996) Experimental soft-sediment deformation: structures formed by the liquefaction of unconsolidated sands and some ancient examples. Sedimentology 43, 279-93.

Pflug HD (1966) Neue Fossilreste aus den Nama-Schichten in Südwest-Afrika. Paläontologische Zeitschrift 40, 14-25.

Pflug HD (1970) Zur Fauna der Nama-Schichten in Südwest-Afrika. I. Pteridinia, Bau und systematische Zugehörigkeit. Palaeontographica, Abteilung A 134, 226-62.

Pflug HD (1971) Neue Fossilfunde im Jung-Präkambrium und ihre Aussagen zur Entstehung der höheren Tiere. Geologische Rundschau 60, 1340-50.

Pflug HD (1972a) The Phanerozoic-Cryptozoic boundary and the origin of the Metazoa. 24th International Geological Congress, Montreal, Canada. Section 1, 58-67.

Pflug HD (1972b) Zur Fauna der Nama-Schichten in Südwest-Afrika. III. Erniettomorpha, Bau und systematische Zugehörigkeit. Palaeontographica, Abteilung A 139, 134-70.

Pillans BJ (2018) Seeing red: some aspects of the geological and climatic history of the Australian arid zone. In On the Ecology of Australia's Arid Zone (ed. H Lambers), pp. 5-43. Cham, Switzerland: Springer.

Pratlong M, Rancurel C, Pontarotti P and Aurelle D (2017) Monophyly of Anthozoa (Cnidaria): why do nuclear and mitochondrial phylogenies disagree? Zoologica Scripta 46, 363-71.

Press WH (1978) Mathematical theory of the waterbed. American Journal of Physics 46, 966-70.

Pu JP, Bowring SA, Ramezani J, Myrow P, Raub TD, Landing E, Mills A, Hodgin E and Macdonald FA (2016) Dodging snowballs: geochronology of the Gaskiers glaciation and the first appearance of the Ediacaran biota. Geology 44, 955-8.

Rasmussen B, Krapež B and Muhling JR (2014) Hematite replacement of iron-bearing precursor sediments in the 3.46-b.y.-old Marble Bar Chert, Pilbara craton, Australia. Geological Society of America Bulletin 126, $1245-58$

Reid LM, García-Bellido DC, Payne JL, Runnegar B and Gehling JG (2017) Possible evidence of primary succession in a juvenile-dominated Ediacara fossil surface from the Flinders Ranges, South Australia. Palaeogeography, Palaeoclimatology, Palaeoecology 476, 68-76.

Retallack GJ (1992) Were the Ediacaran fossils lichenlike organisms? Geological Society of America Abstracts with Program 24, A226-A227.

Retallack GJ (1994) Were the Ediacaran fossils lichens? Paleobiology 20, 523-44.

Retallack GJ (2007) Growth, decay and burial compaction of Dickinsonia, an iconic Ediacaran fossil. Alcheringa: An Australasian Journal of Palaeontology 31, 215-40.

Retallack GJ (2012) Were Ediacaran siliciclastics of South Australia coastal or deep marine? Sedimentology 59, 1208-36.

Retallack GJ (2013) Ediacaran life on land. Nature 493, 89-92.

Retallack GJ (2014) Volcanosedimentary paleoenvironments of Ediacaran fossils in Newfoundland. Geological Society of America Bulletin 126, 619-38.

Retallack GJ (2016) Ediacaran fossils in thin-section. Alcheringa: An Australasian Journal of Palaeontology 40, 583-600.

Retallack GJ (2019) Interflag sandstone laminae, a novel sedimentary structure, with implications for Ediacaran paleoenvironments. Sedimentary Geology 379, 60-76.

Richter R (1955) Die ältesten Fossilien Süd-Afrikas. Senckenbergiana Lethaia 36, 243-89.
Rineau V, Masse J-P and Villier L (2020) A new cladistic insight on comparative anatomy and phylogeny of rudists (Bivalvia, Hippuritida). Journal of Systematic Palaeontology 18, 1243-97.

Rowland SM (2001) Archaeocyaths-a history of phylogenetic interpretation. Journal of Paleontology 75, 1065-78.

Runnegar B (1982) Oxygen requirements, biology and phylogenetic significance of the late Precambrian worm Dickinsonia, and the evolution of the burrowing habit. Alcheringa: An Australasian Journal of Palaeontology 6, 223-39.

Runnegar B (1986) Molecular palaeontology. Palaeontology 29, 1-24.

Runnegar B and Fedonkin MA (1992) Proterozoic metazoan body fossils. In The Proterozoic Biosphere. A Multidisciplinary Study (eds JW Schopf and C Klein), pp. 369-88. Cambridge: Cambridge University Press.

Runnegar B, Pojeta J, Morris NJ, Taylor JD, Taylor ME and McClung G (1975) Biology of the Hyolitha. Lethaia 8, 181-91.

Scholtz G (2002) The Articulata hypothesis - or what is a segment? Organisms Diversity \& Evolution 2, 197-215.

Seaver EC (2003) Segmentation: mono- or polyphyletic? International Journal of Developmental Biology 47, 583-95.

Sedgwick A (1884) On the origin of metameric segmentation and some other morphological questions. Quarterly Journal of Microscopical Science 24, 43-82.

Seilacher A (1955) Spuren und fazies im Unterkambrium. In Beitrage zur Kenntnis des Kambriums in der Salt Range (Pakistan) (eds $\mathrm{OH}$ Schindewolf and A Seilacher), pp. 373-99. Abhandlungen 10. Mainz: Akademie der Wissenschaften und der Literatur zu Mainz, MathematischNaturwissenschaftliche Klasse.

Seilacher A (1989) Vendozoa: organismic construction in the Proterozoic biosphere. Lethaia 22, 229-39.

Seilacher A (1992) Vendobionta and Psammocorallia: lost constructions of Precambrian evolution. Journal of the Geological Society, London 149, 607-13.

Seilacher A (2003) Ediacaran biota: the dawn of animal life in the shadow of giant protists. Paleontological Research 7, 43-54.

Seilacher A (2007) Trace Fossils. Berlin Heidelberg: Springer-Verlag.

Skelton PW (2018) Part N, Volume 1, Chapter 26A: Introduction to the Hippuritida (rudists): shell structure, anatomy, and evolution. Treatise Online 104, 1-37. doi: 10.17161/to.v0i0.7414.

Smith EF, Nelson LL, Tweedt SM, Zeng H and Workman JB (2017) A cosmopolitan late Ediacaran biotic assemblage: new fossils from Nevada and Namibia support a global biostratigraphic link. Proceedings of the Royal Society B: Biological Sciences 284, 20170934. doi: 10.1098/rspb. 2017.0934.

Sperling EA and Vinther $\mathbf{J}$ (2010) A placozoan affinity for Dickinsonia and the evolution of late Proterozoic metazoan feeding modes. Evolution \& Development 12, 201-9.

Sprigg RC (1947) Early Cambrian (?) jellyfishes from the Flinders Ranges, South Australia. Transactions of the Royal Society of South Australia 71, $212-24$.

Sprigg RC (1949) Early Cambrian 'jellyfishes' of Ediacara, South Australia and Mount John, Kimberley district, Western Australia. Transactions of the Royal Society of South Australia 73, 72-99.

Sprigg RC (1988) On the discovery of the Precambrian Ediacaran fossil fauna in South Australia. Earth Sciences History 7, 46-51.

Sprigg RC (1989) Ediacaran fauna revisited. Geotimes October 1989, 8-9.

St Jean J (1973) A new Cambrian trilobite from the piedmont of North Carolina. American Journal of Science 273, 196-216.

Steinmetz PRH (2019) A non-bilaterian perspective on the development and evolution of animal digestive systems. Cell and Tissue Research 377, 321-39.

Steinmetz PRH, Aman A, Kraus JEM and Technau U (2017) Gut-like ectodermal tissue in a sea anemone challenges germ layer homology. Nature Ecology \& Evolution 1, 1535-42.

Stephenson TA (1935) The British Sea-Anemones, Vol. II. London: The Ray Society.

Sun W (1986) Late Precambrian scyphozoan medusa Mawsonites randellensis sp. nov. and its significance in the Ediacara metazoan assemblage, South Australia. Alcheringa: An Australasian Journal of Palaeontology 10, 169-81. 
Tarhan LG, Droser ML, Gehling JG and Dzaugis MP (2017) Microbial ma sandwiches and other anactualistic sedimentary features of the Ediacara Member (Rawnsley Quartzite, South Australia): implications for interpretation of the Ediacaran sedimentary record. Palaios 32, 181-94.

Tarhan LG, Hood AVS, Droser ML, Gehling JG and Briggs DEG (2016) Exceptional preservation of soft-bodied Ediacara Biota promoted by silica-rich oceans. Geology 44, 961-4.

Technau U and Genikhovich G (2018) Evolution: directives from sea anemone Hox genes. Current Biology 28, R1303-R1305.

Tojo B, Saito R, Kawakami S and Ohno T (2007) Theoretical morphology of quilt structures in Ediacaran fossils. In The Rise and Fall of the Ediacaran Biota (eds P Vickers-Rich and P Komarower), pp. 399-404. Geological Society of London, Special Publication no. 286.

Towe KM and Urbanek A (1972) Collagen-like structures in Ordovician graptolite periderm. Nature 237, 443-5.

Twidale CR (2016) Enigmatic Mesozoic paleoforms revisited: the Australian experience. Earth-Science Reviews 155, 82-92.

Vacelet J (1985) Coralline sponges and the evolution of the Porifera. In The Origins and Relationships of Lower Invertebrates: Systematics Association Special Volume 28 (eds S Conway Morris, JD George, R Gibson and HM Platt), pp. 1-13. Oxford: Clarendon Press.

Valentine JW (1992) Dickinsonia as a polypoid organism. Paleobiology 18 378-82.

von Der Lühe B, Birk JJ, Dawson L, Mayes RW and Fiedler S (2018) Steroid fingerprints: efficient biomarkers of human decomposition fluids in soil. Organic Geochemistry 124, 228-37.

Wade M (1968) Preservation of soft-bodied animals in Precambrian sandstones at Ediacara, South Australia. Lethaia 1, 238-67.

Wade M (1971) Bilateral Precambrian chondrophores from the Ediacara fauna South Australia. Proceedings of the Royal Society of Victoria 84, 183-8.

Wade M (1972a) Dickinsonia: polychaete worms from the late Precambrian Ediacara fauna, South Australia. Memoirs of the Queensland Museum 16, 171-90.
Wade M (1972b) Hydrozoa and Scyphozoa and other medusoids from the Precambrian Ediacara fauna, South Australia. Palaeontology 15, 197-225.

Waggoner B (1995) Ediacaran lichens: a critique. Paleobiology 21, 393-7.

Waggoner B and Collins AG (2002) Reductio ad absurdam: testing the evolutionary relationships of Ediacaran and Paleozoic problematic fossils using molecular divergence dates. Journal of Paleontology 78, 51-61.

Walcott CD (1898) Fossil medusae. Monographs of the United States Geological Survey 30, 1-201.

Wang X, Pang K, Chen Z, Wan B, Xiao S, Zhou C and Yuan X (2020) The Ediacaran frondose fossil Arborea from the Shibantan limestone of South China. Journal of Paleontology 94, 1034-50.

Wood DA, Dalrymple RW, Narbonne GM, Gehling JG and Clapham ME (2003) Paleoenvironmental analysis of the late Neoproterozoic Mistaken Point and Trepassey formations, southeastern Newfoundland. Canadian Journal of Earth Sciences 40, 1375-91.

Woodward SP (1855) On the structure and affinities of the Hippuritidæ. Quarterly Journal of the Geological Society 11, 40-61.

Yanishevsky M (1926) Ob ostatkah trubchatyh chervei iz kembriyskoy siney gliny. [On the remains of the tubular worms from the Cambrian blue clays]. Ezhegodnik Russkogo Paleontologicheskogo Obchestva 4, 99-112.

Zakrevskaya MA and Ivantsov AY (2020) Dickinsonia costata from the Late Precambrian of the White Sea. Palaeontological Association Newsletter 105, 28.

Zhang X and Reitner J (2006) A fresh look at Dickinsonia: removing it from Vendobionta. Acta Geologica Sinica 80, 636-42.

Zhao Y, Vinther J, Parry LA, Wei F, Green E, Pisani D, Hou X, Edgecombe GD and Cong P (2019) Cambrian sessile, suspension feeding stem-group ctenophores and evolution of the comb jelly body plan. Current Biology 29, 1112-25.e1-e2. doi: 10.1016/j.cub.2019.02.036.

Zhuravleva IT and Myagkova YI (1972) Archaeata-novaya gruppa organizmov paleozoya [Archaeata-a new group of Paleozoic organisms]. In International Geological Congress, Session XXIV, pp. 7-14. Moscow: Nauka. 